\title{
EDHF: an update
}

Michel Félétou and Paul M. Vanhoutte

Department of Angiology, Institut de Recherches Servier, Suresnes, France and Department of Pharmacology, Faculty of Medicine, University of Hong Kong.

Running title: EDHF

Corresponding Author: Michel Félétou

Department of Angiologie

Institut de Recherches Servier

11 rue des Moulineaux

92150 Suresnes, France

Tel: 01.55 .72 .22 .73

Fax: 01.55.72.80.46

Email: michel.feletou@fr.netgrs.com 


\begin{abstract}
The endothelium controls vascular tone not only by releasing NO and prostacyclin but also by other pathways causing hyperpolarization of the underlying smooth muscle cells. This characteristic was at the origin of the denomination "endothelium-derived hyperpolarizing factor" (EDHF). However, this acronym includes different mechanisms. Arachidonic acid metabolites derived from the cyclooxygenases, lipoxygenases and cytochrome-P450 pathways, $\mathrm{H}_{2} \mathrm{O}_{2}, \mathrm{CO}, \mathrm{H}_{2} \mathrm{~S}$ and various peptides can be released by endothelial cells. These factors activate different families of $\mathrm{K}^{+}$channels and hyperpolarization of the vascular smooth muscle cells contribute to the mechanisms leading to their relaxation. Additionally, another pathway associated with the hyperpolarization of both endothelial and vascular smooth muscle cells contributes also to endothelium-dependent relaxations (EDHF-mediated responses). These responses involve an increase in the intracellular $\mathrm{Ca}^{2+}$ concentration of the endothelial cells followed by the opening of $\mathrm{Ca}^{2+}$-activated $\mathrm{K}^{+}$channels of small and intermediate conductances $\left(\mathrm{SK}_{\mathrm{Ca}}\right.$ and $\left.\mathrm{IK}_{\mathrm{Ca}}\right)$. These channels show a distinct subcellular distribution, $\mathrm{SK}_{\mathrm{Ca}}$ are widely distributed over the plasma membrane while $\mathrm{IK}_{\mathrm{Ca}}$ are preferentially expressed in the endothelial projections toward the smooth muscle cells. Following $\mathrm{SK}_{\mathrm{Ca}}$ activation, smooth muscle hyperpolarization is preferentially evoked by electrical coupling through myo-endothelial gap junctions, while following $\mathrm{IK}_{\mathrm{Ca}}$ activation, potassium efflux can activate smooth muscle Kir2.1 and/or $\mathrm{Na}^{+} / \mathrm{K}^{+}$-ATPase. EDHF-mediated responses are altered by aging and various pathologies. Therapeutic interventions can restore these responses suggesting that the improvement of the EDHF pathway contributes to their beneficial effect. A better characterization of EDHF-mediated responses should allow determining whether or not new drugable targets can be identified for the treatment of cardiovascular diseases.
\end{abstract}

Key words: endothelium, cell membrane potential, potassium channels, myo-endothelial gap junctions, EDHF. 


\section{INTRODUCTION}

Endothelial cells synthesize and release factors that regulate angiogenesis, inflammatory responses, hemostasis as well as vascular tone and permeability. The endothelium maintains the balance between inhibition and promotion of the proliferation and migration of smooth muscle cells, between prevention and stimulation of the adhesion and aggregation of the platelets, between thrombogenesis and fibrinolysis as well as between vasodilatation and vasoconstriction. Upsetting this tightly regulated balance leads to endothelial dysfunction [1,2] (figure 1).

Endothelium-dependent relaxations/vasodilatations in response to neuro-humoral mediators and physical forces, such as the shear stress exerted by the flowing blood, are generally attributed to the release of nitric oxide (NO) and/or prostacyclin $\left(\mathrm{PGI}_{2}\right)$ [3-6]. However, in numerous blood vessels from different species, including the human, these responses cannot be totally explained by the release of these two mediators. The relaxations observed in the presence of inhibitors of cyclooxygenases and NO-synthases are often associated with the hyperpolarization of the vascular smooth muscle cells and were first attributed to a non-characterized endothelial factor termed EDHF for endothelium-derived hyperpolarizing factor. The acronym "EDHF" turned out to be confusing because it implies that a single diffusible substance mediates this type of endothelium-dependent relaxation. In fact NO itself, but also numerous identified putative endothelium-derived factors including carbon monoxide $(\mathrm{CO})$, hydrogen sulfide $\left(\mathrm{H}_{2} \mathrm{~S}\right)$, reactive oxygen species, peptides and arachidonic acid metabolites derived from the cyclooxygenases (COX), lipoxygenases and cytochrome P450 monooxygenases pathways can hyperpolarize the underlying smooth muscle cells [1].

Hyperpolarization decreases $\mathrm{Ca}^{2+}$ influx, either by reducing the open probability of voltage-dependent calcium channels $(\mathrm{Ca})$ or the $\mathrm{Ca}_{V}$-dependent activation of the sarcoplasmic reticulum, which is a powerful mean to produce the relaxation of vascular smooth muscle cells [7-9].

Another pathway, which does not involve the synthesis and the release of a factor per se, is associated with the hyperpolarization of both the endothelial and the vascular smooth muscle cells (EDHF-mediated responses) and contributes also to endothelium-dependent relaxations. These responses involve an increase in the intracellular $\mathrm{Ca}^{2+}$ concentration of the endothelial cells followed by the opening of $\mathrm{Ca}^{2+}$-activated $\mathrm{K}^{+}$channels of small and intermediate conductance ( $\mathrm{SK}_{\mathrm{Ca}}$ and $\mathrm{IK}_{\mathrm{Ca}}$, respectively) and the subsequent hyperpolarization of these cells. Then, the endothelium-dependent hyperpolarization of the underlying smooth muscle cells can be evoked by direct electrical coupling through myo-endothelial junctions and/or the accumulation of $\mathrm{K}^{+}$ions in the intercellular space between the two cell types [1]. The present review will briefly summarize the hyperpolarizing effects of the various endothelial-derived factors and focus on this latter mechanism, i.e. EDHF-mediated responses.

\section{ARACHIDONIC ACID METABOLITES}

\section{CYCLOOXYGENASES}

In the endothelial cells, $\mathrm{PGI}_{2}$ is the principal cyclooxygenase-derived metabolite of arachidonic acid. When activating its preferential receptor, the IP receptor, $\mathrm{PGI}_{2}$ is a potent antithrombotic and antiplatelet agent and is generally a vasodilator substance [3]. The deletion of $\mathrm{PGI}_{2}$-synthase generates hypertensive mice with arterial sclerosis while, in response to stress or injury, the IP receptor knockout animals show enhanced platelet activation, thrombosis, intimal hyperplasia, atherosclerosis, restenosis, and are prone to ischemiareperfusion injury [10]. 
The vascular relaxation to $\mathrm{PGI}_{2}$, or its synthetic analogues, is often associated with the concomitant hyperpolarization of the smooth muscle cells, which, depending on the blood vessels and the species, can involve the opening of various populations of potassium channels $[11,12]$. Therefore, in numerous vascular beds, $\mathrm{PGI}_{2}$ can act as an endothelium-derived hyperpolarizing substance [13]. Since inhibitors of cyclooxygenases abolish the basal and stimulated generation of $\mathrm{PGI}_{2}$, and potent and specific antagonist of the IP receptor block its vasodilator responses [14,15], the contribution of $\mathrm{PGI}_{2}$ in endothelium-dependent responses can reasonably be assessed. This prostaglandin plays a role in flow-mediated vasodilatation $[16,17]$. However, its contribution to acute endothelium-dependent relaxations in response to neuro-humoral mediators is often minimal [1] or can only be observed when the other endothelial pathways have been inhibited $[18,19]$. The contribution of $\mathrm{PGI}_{2}$ to endotheliumdependent responses is increased in eNOS knockout mice [20,21]. Similarly, in human with cardiovascular diseases, COX-2-derived prostaglandins can play a compensatory role for the decreased NO bioavailability [22,23] possibly explaining some of the detrimental cardiovascular effects associated with COX-2 inhibitors [24].

However, in aging and in the course of some cardiovascular diseases $\mathrm{PGI}_{2}$, along with other prostaglandins, can also act as an endothelium-derived contracting factor by activating smooth muscle thromboxane/endoperoxide receptors (TP-receptors) and thus contribute to endothelial dysfunction [14,15,25] (figure 1).

\section{CYTOCHROME P450 MONOOXYGENASES}

Epoxyeicosatrienoic acids (EETs), derived from the endothelial cytochrome P450 2C or 2J epoxygenases, are generally, but not necessarily, vasodilator agents [26,27] while 20hydroxyeicosatetraenoic acid (20-HETE, a metabolite of the cytochrome P450 of the 4A and $4 \mathrm{~F}$ family preferentially located in vascular smooth muscle cells) is a potent endogenous vasoconstrictor of renal, cerebral, coronary, mesenteric and skeletal muscle arteries [28] (figure 1).

EETs play an important role in endothelium-dependent relaxations either as diffusible factors or as essential endothelial intracellular second messenger(s) [29]. When released, they can act as an autocrine agent eliciting endothelium and NO-dependent relaxations [30] or more generally diffuse toward the underlying vascular smooth muscle cells and produce their relaxation [31,32]. In the latter case, 11,12-EET and 14,15-EET, the two predominant diffusible isoforms, activate large conductance calcium-activated potassium channels $\left(\mathrm{K}_{\mathrm{Ca}} 1.1\right.$ or $\mathrm{BK}_{\mathrm{Ca}}$ ) of the vascular smooth muscle cells [33-36]. Experiments performed both in vitro and in vivo on human blood vessels suggest a contribution of EETs to endothelium-dependent relaxations/vasodilatations in coronary and mammary arteries as well as in peripheral muscular and subcutaneous arterioles [37-40].

Cytochrome P450 metabolites play also an important role in the regulation of the kidney circulation and contribute to the long-term regulation of blood pressure and sodium homeostasis. EETs regulate not only regional blood flow, but activate $\mathrm{K}_{\mathrm{ATP}}$ channels in cardiomyocytes, limit platelet aggregation, exert anti-inflammatory actions and improve insulin sensitivity and lipid metabolism. Thus, they can protect the kidney vasculature from injury during renal and cardiovascular diseases, exert cardioprotection and prevent/delay metabolic syndrome and atherogenesis [41-43].

EETs are rapidly metabolized by soluble epoxide hydrolase to form the generally less active dihydroxyeicosatrienoic acids (DHETs). In mice, disruption of the soluble epoxide hydrolase gene produces no or minor decreases in basal arterial blood pressure [44] but protects against myocardial ischemia-reperfusion, heart failure and ischemic stroke [45-47]. In rats, soluble epoxide hydrolase plays an essential role in angiotensin II-induced cardiac hypertrophy [48], which in cardiovascular patients is the most commonn cause of heart failure. Polymorphisms of soluble epoxide hydrolase (EPHX2) have been associated with 
coronary artery diseases, ischemic stroke and insulin resistance [43,49,50]. Potent and selective inhibitors of this enzyme have been designed and are currently undergoing clinical trials for the treatment of hypertension. The additional anti-inflammatory properties of soluble epoxide hydrolase inhibitors make them also attractive for the treatment of chronic kidney disease in patients with cardiometabolic syndrome [51].

\section{LIPOXYGENASES}

In rat and porcine coronary arteries, the 12-lipoxygenase metabolite 12-(S)hydroxyeicosatetraenoic acid (12-S-HETE) can be released by the endothelial cells and evoke relaxation of the vascular smooth muscle by activating $\mathrm{BK}_{\mathrm{Ca}}$ [52].

In rabbit arteries, the generation of 11,12,15-trihydroxyeicosatrienoic acid $(11,12,15$ THETA) by reticulocyte-15-lipoxygenase-I contributes to acetylcholine-induced endothelium-dependent relaxations [53]. In this species, the age-related decrease in hypotension and the endothelium-dependent relaxations induced by acetylcholine are mediated by a decreased synthesis of $11,12,15$-THETAs, associated with a down-regulation of 15-lipoxygenase expression and a reduced activity of the enzyme [54,55]. By contrast, short-term hypercholesterolemia, in the absence of atherosclerotic lesions, and chronic hypoxia increase endothelial 15-lipoxygenase expression, 11,12,15-THETAs production as well as acetylcholine-induced endothelium-dependent relaxations and hypotension [56,57] (figure 1).

However, although a strong case for lipoxygenases derivatives acting as endotheliumderived hyperpolarizing substance can be built in specific arteries and especially in those of the rabbit, most of the EDHF-mediated responses, including that in human arteries, do not appear to involve metabolite of arachidonic acid produced by this pathway $[1,58]$.

\section{ENDOCANNABINOIDS}

In isolated blood vessels or in vivo in anaesthetized animals, endogenous and exogenous cannabinoids usually have vasodilator properties and are likely to play a role in cardiovascular homeostasis [59]. However, the suggestion that anandamide could be an endothelium-derived hyperpolarizing substance has not been substantiated $[1,60]$.

\section{NO-SYNTHASES}

Three different isoforms of an enzyme are able to synthesize NO from L-arginine and molecular oxygen, NO-synthase I (or neuronal, nNOS, NOS-1), NO-synthase II (or inducible, iNOS, NOS-2) and NO-synthase III (or endothelial, eNOS, NOS-3). Under various circumstances such as the presence of NOS inhibitors, low levels of L-arginine or oxidized tetrahydrobiopterin but also under physiological conditions, NO-synthases can generate superoxide anion $\left(\mathrm{O}_{2}^{-{ }^{-}}\right)$, which is reduced to hydrogen peroxide $\left(\mathrm{H}_{2} \mathrm{O}_{2}\right)$, either spontaneously or enzymatically by superoxide dismutase (SOD) $\mathrm{H}_{2} \mathrm{O}_{2}$ can act locally close to its site of production or, since it is an uncharged molecule, diffuse through the cell membrane and act on neighboring cells [5,61-63] (figure 1).

NITRIC OXIDE (NO)

NO is a potent vasodilator and a powerful inhibitor of platelet adhesion and aggregation. The relaxations elicited by NO are generally associated with the stimulation of the cytosolic soluble guanylyl cyclase and the subsequent activation of cyclic guanosine monophosphate (cGMP)-dependent protein kinase (PKG) [5]. NO regulates the activity of various potassium channels and, depending on the vascular beds, the hyperpolarizing effects of NO on vascular smooth muscle cells can substantially contribute to their relaxation [1]. The activation of $\mathrm{BK}_{\mathrm{Ca}}$ channels by $\mathrm{NO}$ contributes to the beneficial effects of currently prescribed drugs associated with the L-arginine-NOS-cGMP pathway, for instance NO donors and phosphodiesterase inhibitors such as sildenafil [64]. 
In contrast to inhibitors of cyclooxygenase, inhibitors of NO-synthase do not necessarily fully inhibit the production of NO. Thus, in their presence, residual NO can still be produced by the endothelial cells and contributes to the relaxation and/or hyperpolarization of the underlying vascular smooth muscle [65]. Furthermore, NO can also be stored and released independently of the activation of NO-synthase [66-68]. Therefore, it seems likely that the role of $\mathrm{NO}$ as an endothelium-derived hyperpolarizing substance may be underestimated by assuming that the presence of an inhibitor of NO-synthases rules out its contribution. A nonNO- non- $\mathrm{PGI}_{2}$-mediated response should be reported not only when a relaxation and/or hyperpolarization is recorded in the combined presence of inhibitors of cyclooxygenases and NO-synthases but when this response is still observed with the additional presence of a NO scavenger [69]. In in vivo studies in human, complete blockade of NO synthase is difficult to achieve (or to demonstrate) and for obvious ethical reasons many of the pharmacological tools used to study EDHF-mediated responses cannot be administrated. The limitation of these studies should always be kept in mind when interpreting these data.

In NOS-3 knockout mice, EDHF-mediated responses play a compensatory role for the absence of endothelial NO [70] and this adaptation to NO synthase deletion is gender specific [71]. Similarly, in resistance arteries from female double knockout mice for NOS-3 and cyclooxygenase-1 (COX-1), endothelium-dependent relaxations are preserved by an EDHFmediated mechanism while, in arteries from the double knockout males, the endotheliumdependent relaxations are impaired severely. In genetically modified female mice, the double deletion of NOS-3 and COX-1 does not affect mean arterial blood pressure while the corresponding males are hypertensive [72].

\section{HYDROGEN PEROXIDE}

In the mesenteric arteries of mice with disruption of the various NOS isoform genes (single NOS-3 knockout, double NOS-1/NOS-3 knockout and triple NOS-1/NOS-2/NOS-3 knockout) the endothelium-dependent relaxations and hyperpolarizations resistant to inhibitors of NO-synthases and cyclooxygenases are progressively reduced as the number of the disrupted NOS genes increased [73]. The dependency of the responses resistant to inhibitors of NO-synthases and cyclooxygenases towards the NOS systems could not be explained by residual $\mathrm{NO}$ release but has been attributed to the production of $\mathrm{H}_{2} \mathrm{O}_{2}$ [73] (figure 1).

Depending on the tissue, the experimental conditions or the concentrations studied, $\mathrm{H}_{2} \mathrm{O}_{2}$ possesses dilator or constrictor properties, and can hyperpolarize or depolarize vascular smooth muscle cells [74]. For instance, in the isolated murine mesenteric artery, $\mathrm{H}_{2} \mathrm{O}_{2}$, at concentrations lower than $50 \mu \mathrm{M}$, produces an endothelium-independent relaxation providing that $\mathrm{K}_{\mathrm{Ca}}$ channels are operational but, at the same concentrations, elicits a potent contractile response if the activity of these channels is compromised [75].

In NOS-disrupted murine arteries, relaxations resistant to inhibitors of NO-synthases and cyclooxygenases are sensitive to catalase, the enzyme that dismutates $\mathrm{H}_{2} \mathrm{O}_{2}$ into water and oxygen, and have been attributed to the NOS-3/Cu,Zn-SOD-dependent formation of $\mathrm{H}_{2} \mathrm{O}_{2}$

[76,77] (figure 1). The maintenance of these endothelium-dependent relaxations/hyperpolarizations in NOS-3 knockout mice was explained by the compensatory endothelial expression of other NOS genes, the production of $\mathrm{H}_{2} \mathrm{O}_{2}$ being preserved up to the total disruption of the three NOS genes [73]. Nevertheless, whether or not the decrease in the EDHF-mediated responses is directly associated with the disruption of the NOS genes or is independently associated with the severe phenotype of these mice, especially with the one observed in the triple knockout mice (hypertension, dyslipidemia, myocardial infarction and nephrogenic diabetes insipidus) remains to be fully assessed (see also the phenotype of mice with deletion of the cystathionine $\gamma$-lyase). 
The involvement of $\mathrm{H}_{2} \mathrm{O}_{2}$ in agonist- and flow-induced endothelium-dependent relaxations/vasodilatations has been suggested in other vascular beds [78], including human mesenteric [79] and coronary arteries [80]. In addition, without actually being released by the endothelial cells, $\mathrm{H}_{2} \mathrm{O}_{2}$ can enhance EDHF-mediated responses by potentiating calcium release from endothelial stores [81]. In various experimental models or in arteries from patients with cardiovascular diseases, $\mathrm{H}_{2} \mathrm{O}_{2}$ generation can partially compensate the decreased NO production, at least in term of endothelium-dependent relaxations, but in the long term this production of reactive oxygen species may contribute to vascular oxidative injury [8284].

Depending on the blood vessels, besides NO-synthases several other endothelial enzymes such as cyclooxygenases, lipoxygenases, cytochrome P450 epoxygenases, NADPH oxidases and mitochondrial respiratory enzymes can generate superoxide anions and be at the origin of $\mathrm{H}_{2} \mathrm{O}_{2}$ production [78]. In murine arteries, endothelial oxidases other than NOS do not appear to be involved in $\mathrm{H}_{2} \mathrm{O}_{2}$-mediated responses [85]. However, in human coronary arterioles flowinduced endothelium-dependent dilation is associated with $\mathrm{H}_{2} \mathrm{O}_{2}$ generated by the mitochondrial respiratory chain, while bradykinin-induced endothelium-dependent relaxation requires NADPH oxidase-derived $\mathrm{H}_{2} \mathrm{O}_{2}[86,87]$.

Therefore, in presence of nitric oxide synthases and cyclooxygenases inhibitors, residual $\mathrm{NO}$ and/or $\mathrm{H}_{2} \mathrm{O}_{2}$, both potentially derived from various endothelial NOS isoforms, can act as endothelium-derived hyperpolarizing substances. However, in many arteries EDHF-mediated responses cannot be attributed to the generation of residual $\mathrm{NO}$ or to that of $\mathrm{H}_{2} \mathrm{O}_{2}[1,74,88]$.

\section{OTHER GASEOUS MEDIATORS}

Besides $\mathrm{NO}, \mathrm{CO}$ and $\mathrm{H}_{2} \mathrm{~S}$ are also water soluble low molecular weight gas that readily cross lipid membranes and therefore diffuse homogeneously and in a non-polarized manner from their production site acting as autocrine and paracrine substances [89].

CARBON MONOXIDE (CO)

The predominant biological source of $\mathrm{CO}$ is from the heme degradation by hemeoxygenase (HO), either from the constitutive (HO-2) or the inducible (HO-1) isoform, both being expressed in vascular smooth muscle and endothelial cells [90,91]. In many physiopathological situations the HO-CO pathway compensates for the decrease NO bioavailability [91]. CO is a potent vasodilator in most, but not all, vascular beds. The mechanisms of COinduced vasodilatation involve the stimulation of soluble guanylate cyclase, the inhibition of cytochrome P450-dependent production of 20-HETE and/or the activation of various populations of $\mathrm{K}^{+}$channels [91]. However, $\mathrm{CO}$ is also a tonic inhibitor of NOS, by binding to its prosthetic heme, and can contribute to endothelial dysfunction [92].

HO-1 knockout mice, although normotensive, when subjected to stress or injury show exacerbated responses. In contrast, overexpression of HO-1 plays a protective role in hypoperfusion and ischemia/reperfusion injury and induction of HO-1 expression by transient hemin administration produces a long-lasting normalization of arterial blood pressure in spontaneously hypertensive rats (SHR) $[93,94]$. HO-2 knockout mice are also normotensive but stroke damage in response to injuries is accentuated in these animals, indicating that HO-2 plays an endogenous neuroprotective role in the brain [95]. Carbon monoxide releasing molecules have vasodilator, anti-ischaemic and anti-inflammatory effects and may present some therapeutic interest in cardiovascular diseases [96].

An endothelial production of $\mathrm{CO}$, contributing to endothelium-dependent relaxations in response to neurohumoral substances, has been demonstrated only in a limited number of arteries and is therefore unlikely to explain most EDHF-mediated responses [1,97,98].

HYDROGEN SULFIDE $\left(\mathrm{H}_{2} \mathrm{~S}\right)$ 
Two main enzymes are responsible for the production of hydrogen sulfide $\left(\mathrm{H}_{2} \mathrm{~S}\right)$, cystathionine $\beta$-synthase and cystathionine $\gamma$-lyase and both use L-cysteine as substrate. The physiological cardiovascular effects of $\mathrm{H}_{2} \mathrm{~S}$, which are generally linked to the activation of the latter enzyme, involve anti-inflammatory and anti-oxidant properties, vasodilatation and a decrease in arterial blood pressure [89,99] (figure 1).

Mice with deletion of the cystathionine $\gamma$-lyase, an enzyme expressed in multiple tissues, and recently identified in the endothelial cells, are hypertensive and the endotheliumdependent relaxations of their mesenteric artery in response to methacholine is virtually abolished [100]. $\mathrm{H}_{2} \mathrm{~S}$ is produced and released by endothelial cells, in a calcium-dependent manner, following neuro-humoral stimulation and evokes relaxation and hyperpolarization of vascular smooth muscle cells by activating $\mathrm{K}_{\mathrm{ATP}}$ channels [100,101]. Thus, these results suggest that $\mathrm{H}_{2} \mathrm{~S}$ is an endothelium-derived relaxing and hyperpolarizing factor. However, the precise role of this mediator needs to be further substantiated. In most studies, the endothelium-dependent relaxations of the murine mesenteric artery involve NO release and EDHF-mediated responses, which are not necessarily associated with the activation of $\mathrm{K}_{\mathrm{ATP}}$ channel [1]. The disappearance of both the NO- and EDHF-mediated component of the endothelium-dependent relaxation in cystathionine $\gamma$-lyase knockout mice is unexplained at present but could be attributed to the increase in homocysteine levels [102,103]. Again, whether or not the decrease in endothelium-dependent responses (NO-mediated and EDHFmediated responses) is directly associated with the disruption of the cystathionine $\gamma$-lyase gene or is independently associated with the phenotype of these mice remains to be determined (see also multiple NOS-knockout mice).

$\mathrm{H}_{2} \mathrm{~S}$ donors are currently been synthesized and have therapeutic potential in cardiovascular diseases associated with inflammatory processes such as reperfusion injury, circulatory shock, atherosclerosis, diabetes and possibly hypertension $[97,104,105]$.

\section{C-TYPE NATRIURETIC PEPTIDE (CNP),}

Endothelial cells can theoretically synthesize numerous vasoactive peptides. Among them CNP, a member of the natriuretic peptide family, evokes relaxations and hyperpolarizations of vascular smooth muscle cells, including those of human forearm resistance vessels. The vasodilator effects of $\mathrm{CNP}$ are generally attributed to the activation of natriuretic peptide receptors B subtype (NPR-B) on the smooth muscle, followed by the stimulation of particulate guanylate cyclase, leading to accumulation of cGMP and the subsequent opening of $\mathrm{BK}_{\mathrm{Ca}}$ and $\mathrm{K}_{\mathrm{ATP}}$ channels [106-108].

Additionally, it has been suggested that CNP could contribute to EDHF-mediated responses. CNP would activate the NPR-C receptor subtype and evoke hyperpolarization of the smooth muscle cell via the cGMP-independent activation of G-protein regulated inwardrectifier $\mathrm{K}^{+}$channels (GIRK) [109,110]. However, this hypothesis had not been confirmed [111-113] and in mice deficient for the NPR-C gene, EDHF-mediated responses are not altered [114].

Therefore, CNP is unlikely to act as an endothelium-derived relaxing/hyperpolarizing substance and contribute to moment-to-moment endothelium-dependent regulation of vascular tone. Nevertheless, this peptide plays a key role in preventing smooth muscle proliferation, leukocyte recruitment and platelet reactivity. As such, CNP is likely to exert an anti-atherogenic influence on the blood vessel walls $[115,116]$.

\section{EDHF-MEDIATED RESPONSES}

EDHF-mediated responses are endothelium-dependent relaxations resistant to inhibitors of NO-synthases and cyclooxygenases, which do not involve one of the identified mediators 
mentioned above (arachidonic acid metabolites, residual or stored $\mathrm{NO}, \mathrm{H}_{2} \mathrm{O}_{2}, \mathrm{CO}, \mathrm{H}_{2} \mathrm{~S}, \mathrm{CNP}$ ), and which require the activation of endothelial calcium-activated potassium channels.

\section{CALCIUM-ACTIVATED POTASSIUM CHANNELS}

The three subtypes of calcium-activated potassium channels of large $\left(\mathrm{BK}_{\mathrm{Ca}}\right)$, intermediate $\left(\mathrm{K}_{\mathrm{Ca}} 3.1\right.$ or $\left.\mathrm{IK}_{\mathrm{Ca}}\right)$ and small conductance $\left(\mathrm{K}_{\mathrm{Ca}} 2.3\right.$ isoform or $\left.\mathrm{SK}_{\mathrm{Ca}}\right)$ are present in the vascular wall but with very specific cellular and subcellular localization (figure 2).

$\mathrm{BK}_{\mathrm{Ca}}$ channels are expressed in virtually all vascular smooth muscle cells [1] while in most endothelial cells, when freshly isolated, $\mathrm{BK}_{\mathrm{Ca}}$ channels are at best poorly expressed and iberiotoxin-sensitive currents are observed only at very positive potentials [117-119]. In smooth muscle cells, $\mathrm{BK}_{\mathrm{Ca}}$ channels, often clustered in groups of 20-100 units, are activated by a general increase in intracellular calcium or by calcium sparks, localized elemental calcium release events from internal calcium stores, which then generate spontaneous transient outward currents (STOC) $[120,121]$. $\mathrm{BK}_{\mathrm{Ca}}$ channels are often colocalized in discrete smooth muscle area with endoplasmic reticulum and form signal complex, physically associated with cationic channels such the canonical transient receptor potential channel 1 (TRPC1) [122] or indirectly associated with the vanilloid transient receptor potential channel 4 (TRPV4). The $\mathrm{Ca}^{2+}$ influx through TRPV4 preferentially stimulates ryanodine receptors located on the endoplasmic reticulum increasing the frequency of $\mathrm{Ca}^{2+}$ sparks. In some arteries, EETs-induced hyperpolarization involves the latter $\mathrm{Ca}^{2+}$-signaling complex [36] (figure 2). Conversely, there is little evidence for a functional role of $\mathrm{SK}_{\mathrm{Ca}}$ channels in vascular smooth muscle cells, although a non-identified apamin-sensitive conductance has been reported in some arteries [123-125]. Similarly, in healthy and freshly isolated vascular smooth muscle cells $\mathrm{IK}_{\mathrm{Ca}}$ channels are not or very poorly expressed. However, in proliferating cells, as seen in culture or after vascular injury, the expression of this channel increases dramatically $[126,127]$.

By contrast, the $\mathrm{IK}_{\mathrm{Ca}}$ and $\mathrm{SK}_{\mathrm{Ca}}$ channels (especially the SK3 $\alpha$ subunit) are constitutively expressed in endothelial cells $[117,118,128,129]$, but show a very different spatial distribution. $\mathrm{SK}_{\mathrm{Ca}}$ are diffusely distributed over the plasma membrane with preferential locations at sites of homocellular endothelial gap junctions and caveolin-rich domains and are associated with various connexins $(\mathrm{Cx})$. $\mathrm{IK}_{\mathrm{Ca}}$ are localized preferentially within the endothelial projections through the internal elastic lamina at the sites of myo-endothelial gap junctions [113,130-133] (figure 2).

Agonists that stimulate $\mathrm{G}$ protein-coupled receptors and compounds, such as the calcium ionophore A23187, thapsigargin, and cyclopiazonic acid, evoke EDHF-mediated responses. These substances share the property to increase endothelial intracellular $\mathrm{Ca}^{2+}$ concentration and to activate endothelial $\mathrm{SK}_{\mathrm{Ca}}$ channels (blocked by apamin, scyllatoxin, or UCL 1684) and/or $\mathrm{IK}_{\mathrm{Ca}}$ channels (blocked by charybdotoxin or TRAM-34) [1]. 1-Ethyl-2benzimidazolinone (1-EBIO), a non-specific activator of $\mathrm{K}_{\mathrm{Ca}}$ [134], which activates endothelial $\mathrm{IK}_{\mathrm{Ca}}$ and $\mathrm{SK}_{\mathrm{Ca}}$ [118], but not $\mathrm{BK}_{\mathrm{Ca}}$ channels of vascular smooth muscle, hyperpolarizes endothelial cells and produces endothelium-dependent hyperpolarization $[135,136]$. Similar results were obtained with more potent analogues of 1-EBIO, such as DCEBIO or NS-309 [137,138] and with derivatives of the neuroprotective agent riluzole such as SK-20 or SK-31 [139], indicating that activation of endothelial $\mathrm{K}_{\mathrm{Ca}}$ channels and/or endothelial cell hyperpolarization elicit(s) EDHF-mediated responses.

The hyperpolarization of the endothelial cells in turn favours the entry of calcium by increasing the driving force for this ion [140,141]. Therefore, endothelial $\mathrm{K}_{\mathrm{Ca}}$ channels are not only key players in EDHF-mediated responses but also contribute to the activation of calcium-sensitive enzymes such as eNOS and thus to the generation of NO [142,143] (figure 2).

HYPERPOLARIZATION OF VASCULAR SMOOTH MUSCLE 
The involvement of two populations of endothelial $\mathrm{K}_{\mathrm{Ca}}$ channels in EDHF-mediated responses has been puzzling for a long time but the discrete role of each channel is now better appreciated.

In the blood vessel wall, gap-junctions link smooth muscle with other smooth muscle cells, endothelial with other endothelial cells and in many blood vessels smooth muscle with endothelial cells. The connexins (Cx) 37, 40 and 43 are the predominant isoforms of gapjunction proteins expressed in the vascular wall and, in rodents the $\mathrm{Cx} 37$ and $\mathrm{Cx} 40$ isoforms are involved preferentially in myoendothelial gap junction communication [144-146] (figure 2). The number of myo-endothelial gap junctions increases with a reduction in the size of the artery [147], a phenomenon that parallels the contribution of the EDHF-mediated responses to endothelium-dependent relaxations [148,149]. Endothelium and smooth muscle cells can communicate via these myo-endothelial gap junctions physically, as $\mathrm{Ca}^{2+}$ and $\mathrm{IP}_{3}$ can diffuse from one cell type to another [150-152], and electrically, since depolarization and hyperpolarization are conducted bi-directionally from one cell type to the other [151-156]. However, endothelium-dependent dilatations do not simply propagate electronically but involve a regenerative mechanism [155,157]. Blockers of gap junctions abolish or partially inhibit EDHF-like responses in many arteries and in the rat mesenteric artery, antibodies directed against $\mathrm{Cx} 40$, when loaded selectively in the endothelial cells, block EDHF-mediated responses [144,158-160]. Furthermore, in mice, Cx40 is essential for the acetylcholineactivated regenerative endothelium-dependent vasodilatation [157,162]. Activation of either $\mathrm{SK}_{\mathrm{Ca}}$ or $\mathrm{IK}_{\mathrm{Ca}}$ leads to endothelium-dependent hyperpolarizations and relaxations of vascular smooth muscle cells, but in quiescent arteries (in the absence of vasoconstrictor stimulation) EDHF-mediated responses are associated with the preferential activation of $\mathrm{SK}_{\mathrm{Ca}}$ and the contribution of myoendothelial gap junctions [113,131,133,163].

Taken into conjunction, the results of these in vitro experiments provide compelling evidence for a major contributing role of myoendothelial gap junction in EDHF-mediated responses [164]. However, experiments performed in vivo generally failed to demonstrate such a significant role for myoendothelial gap junctions $[165,166]$. The origin of this discrepancy is unknown but may involve the type and size of arteries studied in vivo, the presence of shear stress, sympathetic innervation and circulating hormones as well as confounding factors such as the use of anesthetics which inhibit gap junctions [131,164].

Additionally, the efflux of $\mathrm{K}^{+}$ions associated with the activation of endothelial $\mathrm{K}_{\mathrm{Ca}}$ can contribute to EDHF-mediated responses [166]. The resultant moderate increase in the extracellular $\mathrm{K}^{+}$concentration $(1$ to $15 \mathrm{mM}$ ) can provoke the relaxation of vascular smooth muscle cells [167] by activating $\mathrm{K}_{\mathrm{IR}}$ [168] and the $\mathrm{Na}^{+} / \mathrm{K}^{+}$pump [169]. The activation of $\mathrm{K}_{\mathrm{IR}}$ and the $\mathrm{Na}^{+} / \mathrm{K}^{+}$pump overcomes the small depolarizing effects linked to the increase in potassium ions per se and the net resultant is hyperpolarization and thus relaxation of the smooth muscle cells. This hypothesis was first demonstrated successfully in the hepatic and mesenteric arteries of the rat [166] and observed in many other blood vessels including human arteries [170-177].

However, this phenomenon is likely to occur only in specialized microdomains situated in the endothelial projections associated with myo-endothelial gap junctions. Section of endoplasmic reticulum densely expressing 1,4,5-trisphosphate $\left(\mathrm{IP}_{3}\right)$ receptors, $\mathrm{Cx} 40, \mathrm{IK}_{\mathrm{Ca}}$ channels and calcium-sensing receptors are colocated in these endothelial projections $[113,130-133,178]$. Repetitive localized calcium events (pulsars), driven by $\mathrm{IP}_{3}$ and/or $\mathrm{Ca}^{2+}$ ions (calcium-induced calcium release), originate from these endothelial calcium stores. $\mathrm{IP}_{3}$ can be generated by the endothelial cells (for instance following acetylcholine stimulation) or by the smooth muscle cells (for instance following phenylephrine stimulation). In the latter case, $\mathrm{IP}_{3}$ would diffuse toward the endothelial cells (possibly with $\mathrm{Ca}^{2+}$ ions) through the myoendothelial gap junctions $[113,133,179,180]$. The closely situated $\mathrm{IK}_{\mathrm{Ca}}$ channels are 
activated by these calcium pulsars and the resultant endothelial hyperpolarization can be transmitted to the smooth muscle cells either via the myo-endothelial gap junctions, as described previously, or be elicited by the $\mathrm{K}^{+}$ions accumulating in the restricted extracellular space surrounding these endothelial projections (figure 3 ). In the rat mesenteric artery, $\mathrm{K}^{+}$ion accumulation preferentially activates the $\mathrm{Na}^{+} / \mathrm{K}^{+}$pump $[113,181]$.

The precise role of the calcium-sensing receptor at the site of these endothelial projections is not completely understood. Stimulation of the calcium-sensing receptor results in selective $\mathrm{IK}_{\mathrm{Ca}}$-dependent endothelial hyperpolarization and endothelium-dependent vascular smooth muscle hyperpolarization [178,182,183]. In quiescent arteries (in the absence of vasoconstrictor stimulation), the calcium-sensing receptor would be fully stimulated by the concentration of calcium bathing the endothelial cells and $\mathrm{IK}_{\mathrm{Ca}}$ inactivated [113]. Stimulation of smooth muscle (for instance by phenylephrine) opens $\mathrm{CaV}$ and, in the small extracellular space surrounding myoendothelial projections, could create a localized calcium sink. The endothelial calcium-sensing receptor would detect the changes in extracellular calcium and allow the recruitment of endothelial $\mathrm{IK}_{\mathrm{Ca}}$. The subsequent endothelium-dependent hyperpolarization would restrain excessive activation of the smooth muscle [113] (figure 3). Indeed, reducing the extracellular calcium concentration enables $\mathrm{IK}_{\mathrm{Ca}}$ activation by acetylcholine $[113,163]$. Therefore, endothelial projections and myo-endothelial gap junctions are key structures intrinsically associated with extracellular and intracellular calcium homeostasis in both endothelial and vascular smooth muscle cells $[113,131,133]$.

However, in some blood vessels, $\mathrm{K}^{+}$does not evoke, or inconsistently produces relaxations and hyperpolarizations [136,159,160,184,185], indicating that in these blood vessels the contribution of $\mathrm{K}^{+}$ions in EDHF-mediated responses must be, if anything, minimal. The involvement of gap junctions and $\mathrm{K}^{+}$ions are not necessarily mutually exclusive. The relative proportion of each mechanism almost certainly depends on numerous parameters including the extracellular concentrations in potassium and calcium ions associated with the state of activation of the underlying vascular smooth muscle cells, the density of myo-endothelial gap junctions and the level of the expression of the appropriate isoforms of $\mathrm{Na}^{+} / \mathrm{K}^{+}$-ATPase and/or $\mathrm{K}_{\mathrm{IR}}[1,131]$.

GENETICALLY MODIFIED ANIMALS

In transgenic mice with SK3 gene expression under the control of dietary doxycycline, the suppression of SK3 expression in the endothelial cells depolarizes both the endothelial and the vascular smooth muscle cells, reduces the diameter of resistance vessels in situ and increases arterial blood pressure, a reversible phenotype upon restoration of endothelial SK3 expression [186]. Disruption of the IK1 gene reduces the hyperpolarization of endothelial and smooth muscle cells in response to acetylcholine and decreases the associated vasodilatation, because of a substantial reduction in EDHF-mediated responses. Moreover, the IK1 deletion also led to a significant increase in arterial blood pressure and to mild left ventricular hypertrophy [187]. In double knockout mice, lacking both SK3 and IK1, an addition of the detrimental effects provoked by the deletion of either gene is observed $[188,189]$. These results confirm that in mice endothelial $\mathrm{SK}_{\mathrm{Ca}}$ and $\mathrm{IK}_{\mathrm{Ca}}$ channels are fundamental determinants of endothelial hyperpolarization and EDHF signaling and indicate that they actively control vascular tone and contribute to the overall regulation of the circulation.

Connexins 37 and 40 are the predominant gap junction proteins in murine endothelial cells [190]. Connexin 40 proteins are involved in endothelial homocellular gap junctions and also in heterocellular gap junctions linking endothelial cells not only to smooth muscle cells but also to renin-producing juxtaglomerular cells. The presence of the latter gap junction communication is required in order to maintain the calcium-dependent inhibitory effects of angiotensin II and that of intrarenal pressure on renin secretion and synthesis, suggesting that the endothelium is strongly involved in the regulation of the renin system. Mice deficient for 
connexin 40 are hypertensive. However, alteration in the control of renin release only partially explained the hypertension observed in connexin 40 knockout mice [191]. The arterioles of these animals also exhibit a reduced spread of dilatation in response to endotheliumdependent vasodilators and irregular arteriolar vasomotion [192-194].

Theses results show that deletion of each key molecular component of EDHF-mediated responses is associated with hemodynamic alterations suggesting that this endothelial pathway contributes to the overall regulation of arterial blood pressure.

\section{ENDOTHELIAL DYSFUNCTION AND THERAPEUTIC INTERVENTIONS}

Endothelial dysfunction, observed in various cardiovascular diseases, is associated with a decrease of NO synthesis and/or a loss of its biological activities. However, alteration of the EDHF pathway can also contribute to these endothelial dysfunctions or conversely compensate for the loss in NO bioavailability. Alterations of EDHF-mediated responses have been reported with aging and under various pathological conditions (hypertension, atherosclerosis, hypercholesterolemia, heart failure, ischemia-reperfusion, angioplasty, eclampsia, diabetes, sepsis) $[1,2,195]$.

No drug is available which has been designed to target EDHF-mediated responses. Nevertheless, therapeutic interventions, with beneficial effects on the cardiovascular system such as angiotensin converting enzyme inhibitors, antagonists of angiotensin receptors and phosphodiesterase-3 inhibitors [1,195] can restore these responses, suggesting that the improvement of the EDHF pathway contributes to the observed beneficial effect. Similarly, various so-called non-pharmacological therapeutic strategies including exercise and supplementation with estrogens, omega-3 polyunsaturated fatty acids, polyphenol derivatives, potassium and/or calcium help to reverse endothelial dysfunction including blunted EDHFmediated responses [1,195].

The improvement or restoration of EDHF responses has not been, yet, the direct purpose of any pharmaceutical effort. SKA-31, a preferential activator of murine $\mathrm{IK}_{\mathrm{Ca}}$, potentiates EDHFmediated responses in vitro and lowers mean arterial blood pressure in normotensive and in angiotensin II-hypertensive mice [139]. However, $\mathrm{IK}_{\mathrm{Ca}}$ channels are required for the differentiation of vascular smooth muscle cells, as well for their proliferation and migration [126,127,197,198]. Selective blockade of $\mathrm{IK}_{\mathrm{Ca}}$ with TRAM-34 [199] prevents phenotypic changes of smooth muscle and coronary artery neointimal formation in two different models of post-angioplasty restenosis and the development of atherosclerosis in ApoE(-/-) mice $[126,198,200] \mathrm{IK}_{\mathrm{Ca}}$ are also involved in the proliferation of endothelial [201] and various cancerous cells [202,203]. Therefore, activators of $\mathrm{IK}_{\mathrm{Ca}}$ may have some unwanted detrimental effects.

Additionally, activation of endothelial TRP and $\mathrm{SK}_{\mathrm{Ca}}$ channels, calcium sensing receptors, smooth muscle $\mathrm{K}_{\mathrm{IR}}$ and/or specific isoform(s) of $\mathrm{Na}^{+} / \mathrm{K}^{+}$-ATPase as well as facilitating myo-endothelial communication and increasing the expression of appropriate connexins, channels and receptors may represent new potential targets. However, the precise role of these various molecular elements is far from being completely understood. For instance, TRPV4 channel could appear as a promising target in cardiovascular diseases since this cationic channel is involved in calcium entry following endothelial stimulation. [204]. Indeed, the arterial responses to shear stress critically depend on the activation of this endothelial channel and both the NO and the EDHF-mediated components of acetylcholineinduced vasodilatation are attenuated in TRPV4-deficient mice [205,206]. However, GSK1016790A, a specific and potent agonist, which as expected increases endothelial intracellular calcium concentration and produces endothelium-dependent relaxations, also causes endothelial failure, circulatory collapse and death [207]. Rotigaptide (ZP123), an antiarrhythmic peptide that prevents uncoupling of $\mathrm{Cx} 43$-mediated gap junction communication [208], has no effect on basal vascular tone and does not enhance endothelium- 
dependent or independent vasodilatation in the forearm arterial circulation of healthy subjects [209]. Whether or not augmenting Cx43 communication would improve endothelial function in patients with vascular disease and whether or not $\mathrm{Cx} 40$, in human, would be a more appropriate target than $\mathrm{Cx} 43$ remain to be determined.

\section{CONCLUSION AND PERSPECTIVES}

Endothelial cells control the tone of the underlying vascular smooth muscle by releasing numerous vasoactive substances, including NO, reactive oxygen species, potassium ions and metabolites of arachidonic acid (e.g; prostacyclin, EETs, lipoxygenase derivatives). Furthermore, the endothelial monolayer behaves as a conductive tissue propagating an electrical signal along the axis of the blood vessel by means of homocellular gap junctions and throughout the vascular wall itself by means of myo-endothelial gap junctions. Endotheliumdependent relaxations, independent of the production of NO and prostacyclin, probably play an important role in cardiovascular physiology in numerous animal species and in the human. They can act as a back up system when NO is inhibited or reduced but this is not necessarily the case.

However, it is often difficult to reach a conclusion as to the true importance of endothelium-dependent hyperpolarizations because of the use of unspecific pharmacological tools and the lack of electrophysiological measurements. The mechanisms underlying endothelium-responses must be carefully dissected in order to be properly identified. The synthesis of more selective compounds such as non-peptidic inhibitors and activators of $\mathrm{SK}_{\mathrm{Ca}}$ and $\mathrm{IK}_{\mathrm{Ca}}$ may in the future allow the selective blockade/activation of EDHF-mediated responses and hence the proper determination of their physiological role in the human circulation. The limited information available suggests that if better (i.e. more potent, more specific and if possible orally active) pharmacological tools were developed to modulate the role of the various molecular constituents underlying EDHF-mediated responses, it may be possible to determine whether or not putative cardiovascular targets identified within this pathway are drugable. 


\section{REFERENCES}

1 Félétou, M. and Vanhoutte, P.M. (2005) EDHF: the complete story, Taylor \& Francis, CRC press; Boca Raton, Fl.

2 Félétou, M. and Vanhoutte, P.M. (2006) Endothelial dysfunction: a multifaceted disorder (The Wiggers Award Lecture). Am. J. Physiol. Heart Circ. Physiol. 291, H985H1002.

3 Moncada, S. and Vane, J.R. (1979) Pharmacology and endogenous roles of prostaglandin endoperoxides, thromboxane A2 and prostacyclin. Pharmacol. Rev. 30, 293-331.

4 Furchgott, R.F. and Zawadzki, J.V. (1980) The obligatory role of the endothelial cells in the relaxation of arterial smooth muscle by acetylcholine. Nature. 288, 373-376.

5 Moncada, S., Palmer, R.J.M. and Higgs, E.A. (1991) Nitric oxide: Physiology, Pathophysiology, and Pharmacology. Pharmacol. Rev. 43, 109-142.

6 Furchgott, R.F. and Vanhoutte, P.M. (1989) Endothelium-derived relaxing and contracting factors. FASEB J. 3, 2007-2018.

7 Nelson, M.T., Huang, Y., Brayden, J.E., Hescheler, J. and Standen, N.B. (1990) Arterial dilations in response to calcitonin gene related peptide involve activation of $\mathrm{K}^{+}$ channels. Nature 344, 770-773.

8 Bolton, T.B., Gordienko, D.V., Pucovsky, V., Parsons, S. and Povstyan, O. (2002) Calcium release events in excitation-contraction coupling in smooth muscle. Novartis Found Symp. 246, 154-168.

9 Del Valle-Rodriguez, A., Lopez-Barneo, J. and Urena, J. (2003) $\mathrm{Ca}^{2+}$ channelsarcoplasmic reticulum coupling: a mechanism of arterial myocyte contraction without $\mathrm{Ca}^{2+}$ influx. EMBO J. 22, 4337-4345.

10 Smyth, E.M. and FitzGerald, G.A. (2002) Human prostacyclin receptor. Vitam. Horm. 65,149-165.

11 Félétou, M. and Vanhoutte, P.M. (2007) Endothelium-dependent hyperpolarizations: past beliefs and present facts. Ann Med. 39, 495-516.

12 Corriu, C., Félétou, M., Edwards, G., Weston, A.H. and Vanhoutte, P.M. (2001) Differential effects of Prostacyclin and Iloprost in the isolated carotid artery of the guinea-pig. Eur. J. Pharmacol. 426, 89-94.

13 Parkington, H., C., Coleman, H.A., Tare M. (2004) Prostacyclin and endotheliumdependent hyperpolarization. Pharmacol. Res. 49, 509-514

14 Gluais, P., Lonchampt, M., Morrow, J.D., Vanhoutte, P.M. and Félétou, M. (2005) Acetylcholine-induced endothelium-dependent contractions in the SHR aorta: the Janus face of prostacyclin. Br. J. Pharmacol. 146, 834-845.

15 Gomez, E., Schwendemann, C., Roger, S., Simonet, S., Paysant, J., Courchay, C., Verbeuren, T.J. and Félétou M. (2008) Aging and prostacyclin responses in aorta and platelets from WKY and SHR rats. Am. J. Physiol. Heart Circ. Physiol. 295, H2198H2211.

16 Koller, A., Sun, D. and Kaley, G. (1993) Role of shear stress and endothelial prostaglandins in flow- and viscosity-induced dilation of arterioles in vitro. Circ. Res. 72, 1276-1284.

17 Duffy, S.J., Tran, B.T., New, G., Tudball, R.N., Esler, M.D., Harper, R.W. and Meredith, I.T. (1998) Continuous release of vasodilator prostanoids contributes to regulation of resting forearm blood flow in humans. Am. J. Physiol. 274, H1174H1183. 
18 Corriu, C., Félétou, M., Canet, E. and Vanhoutte, P.M. (1996) Endothelium-derived factors and hyperpolarisations of the isolated carotid artery of the guinea-pig. Br. J. Pharmacol. 119: 959-964.

19 Zygmunt, P.M., Plane F., Paulsson, M., Garland, C.J., Högestätt, E.D. (1998) Interactions between endothelium-derived relaxing factors in the rat hepatic artery: focus on regulation of EDHF. Br. J. Pharmacol. 124: 992-1000.

20 Chataigneau, T., Félétou, M., Huang, P.L., Fishman, M.C., Duhault, J., Vanhoutte, P.M. (1999) Acetylcholine-induced relaxation in blood vessels from endothelial nitric oxide synthase knockout mice. Br. J. Pharmacol. 126: 219-226.

21 Sun, D., Huang, A., Smith, C.J., Stackpole, C.J., Connetta, J.A., Shesely, E.G., Koller, A. and Kaley, G. (1999) Enhanced release of prostaglandins contributes to flow-induced arteriolar dilation in eNOS knockout mice. Circ. Res. 85, 288-293.

22 Bulut, D., Liaghat, S., Hanefeld, C., Koll, R., Miebach, T. and Mügge, A. (2003) Selective cyclo-oxygenase-2 inhibition with parecoxib acutely impairs endotheliumdependent vasodilatation in patients with essential hypertension. J. Hypertens. 21, 1663 1667.

23 Szerafin, T., Erdei, N., Fülöp, T., Pasztor, E.T., Edes, I., Koller, A. and Bagi, Z. (2006) Increased cyclooxygenase- 2 expression and prostaglandin-mediated dilation in coronary arterioles of patients with diabetes mellitus. Circ. Res. 99, e12-17.

24 Andersohn, F., Suissa, S. and Garbe, E. (2006) Use of first- and second-generation cyclooxygenase-2-selective nonsteroidal antiinflammatory drugs and risk of acute myocardial infarction. Circulation. 113, 1950-1957.

25 Vanhoutte, P.M. and Tang, E.H. (2008) Endothelium-dependent contractions: when a good guy turns bad! J Physiol. 586: 5295-5304.

26 Fleming, I. (2004) Cytochrome P450 epoxygenases as EDHF synthase(s). Pharmacol Res. 49, 525-33.

27 Chataigneau, T., Félétou, M., Duhault, J. and Vanhoutte, P.M. (1998) Epoxyeicosatrienoic acids, potassium channel blockers and endothelium-dependent hyperpolarisation in the guinea-pig carotid artery. Br. J. Pharmacol. 123, 574-580.

28 Miyata, N. and Roman, R.J. (2005) Role of 20-hydroxyeicosatetraenoic acid (20-HETE) in vascular system. J. Smooth Muscle Res. 41, 175-93.

29 Fleming, I. (2008) Vascular cytochrome p450 enzymes: physiology and pathophysiology. Trends Cardiovasc Med. 18, 20-25.

30 Hercule, H.C., Schunck, W.H., Gross, V., Seringer, J., Leung, F.P., Weldon, S.M., da Costa Goncalves, A.C., Huang, Y., Luft, F.C. and Gollasch, M. (2009) Interaction Between P450 Eicosanoids and Nitric Oxide in the Control of Arterial Tone in Mice. Arterioscler. Thromb. Vasc. Biol. 29, 54-60.

31 Campbell, W.B., Gebremedhin, D., Pratt, P.F. and Harder, D.R. (1996) Identification of epoxyeicosatrienoic acids as endothelium-derived hyperpolarizing factor. Circ Res. 78, 415-423.

32 Fisslthaler, B., Popp, R., Kiss, L., Potente, M., Harder, D.R., Fleming, I. and Busse, R. (1999) Cytochrome P4540 2C is an EDHF synthase in coronary arteries. Nature 401, 493-497.

33 Gauthier, K.M., Edwards, E.M., Falck, J.R., Reddy, D.S. and Campbell, W.B. (2005) 14,15-Epoxyeicosatrienoic acid represents a transferable endothelium-dependent relaxing factor in bovine coronary arteries. Hypertension. 45, 666-671.

34 Huang, A., Sun, D., Jacobson, A., Carroll, M.A., Kalck, J.R. and Kaley, G. (2005) Epoxyeicosatrienoic acids are released to mediate shear stress-dependent hyperpolarization of arteriolar smooth muscle. Circ. Res. 96, 376-383. 
35 Weston, A.H., Félétou, M., Vanhoutte, P.M., Falck, J.R., Campbell, W.B. and Edwards, G. (2005) Endothelium-dependent hyperpolarizations induced by bradykinin in the vasculature; clarification of the role of epoxyeicosatrienoic acids. Br. J. Pharmacol. 145, 775-784.

36 Earley, S., Heppner, T.J., Nelson, M.T. and Brayden, J.E. (2005) TRPV4 forms a novel $\mathrm{Ca}^{2+}$-signaling complex with ryanodine receptors and $\mathrm{BK}_{\mathrm{Ca}}$ channels. Circ. Res. 97, 1270-1279.

37 Miura, H. and Gutterman D.D. (1998) Human coronary arteriolar dilation to arachidonic acid depends on cytochrome $\mathrm{P} 450$ monooxygenase and $\mathrm{Ca}^{2+}$-activated $\mathrm{K}^{+}$channels. Circ. Res. 83, 501-507.

38 Archer, S.L., Gragasin, F.S., Wu, X., Wang, S., McMurthry, S., Kim, D.H., Platonov, M., Koshal, A., Hashimoto, K., Campbell, W.B., Falck, J.R. and Michelakis, E.D. (2003) Endothelium-derived hyperpolarizing factor in human internal mammary artery is 11,12 -epoxieicosatrienoic acid and causes relaxation by activating $\mathrm{BK}(\mathrm{Ca})$ channels. Circulation 107, 769-776.

39 Coats, P., Johnston, F. MacDonald, J., McMurray, J.J. and Hillier, C. (2001) Endothelium-derived hyperpolarizing factor: identification and mechanisms of action in human subcutaneous resistance arteries. Circulation 103, 1702-1708.

40 Bellien, J., Thuillez, C. and Joannides, R. (2008) Contribution of endothelium-derived hyperpolarizing factors to the regulation of vascular tone in humans. Fundam. Clin. Pharmacol. 22, 363-377.

41 Imig, J.D. (2005) Epoxide hydrolase and epoxygenase metabolites as therapeutic targets for renal diseases. Am. J. Physiol. Renal Physiol. 289, F496-F503.

42 Larsen, B.T., Campbell, W.B. and Gutterman, D.D. (2007) Beyond vasodilatation: nonvasomotor roles of epoxyeicosatrienoic acids in the cardiovascular system. Trends Pharmacol. Sci. 28, 32-38.

43 Gauthier, K.M., Yang, W., Gross, G.J. and Campbell, W.B. (2007) Roles of epoxyeicosatrienoic acids in vascular regulation and cardiac preconditioning. $\mathrm{J}$. Cardiovasc. Pharmacol. 50, 601-608.

44 .Luria, A., Weldon, S.M., Kabcenell, A.K., Ingraham, R.H., Matera, D., Jiang, H., Gill, R., Morisseau, C., Newman, J.W. and Hammock B.D. (2007) Compensatory mechanism for homeostatic blood pressure regulation in Ephx2 gene-disrupted mice. $\mathrm{J}$ Biol Chem. 282, 2891-2898.

45 Motoki, A., Merkel, M.J., Packwood, W.H., Cao, Z., Liu, L., Iliff, J.J., Alkayed, N.J. and Van Winkle, D.M. (2008) Soluble Epoxide Hydrolase Inhibition and Gene Deletion Are Protective Against Myocardial Ischemia-Reperfusion Injury In Vivo. Am. J. Physiol. Heart Circ Physiol. 295, H2128-H2134.

46 Monti, J., Fischer, J., Paskas, S., Heinig, M., Schulz, H., Gösele, C., Heuser, A., Fischer, R., Schmidt, C., Schirdewan, A., Gross, V., Hummel, O., Maatz, H., Patone, G., Saar, K., Vingron, M., Weldon, S.M., Lindpaintner, K., Hammock, B.D., Rohde, K., Dietz, R., Cook, S.A., Schunck, W.H., Luft, F.C. and Hubner, N. (2008) Soluble epoxide hydrolase is a susceptibility factor for heart failure in a rat model of human disease. Nat. Genet. 40, 529-537.

47 Zhang, W., Otsuka, T., Sugo, N., Ardeshiri, A., Alhadid, Y.K., Iliff, J.J., DeBarber, A.E., Koop, D.R. and Alkayed, N.J. (2008) Soluble epoxide hydrolase gene deletion is protective against experimental cerebral ischemia. Stroke. 39, 2073-2078.

48 Ai, D., Pang, W., Li, N., Xu, M., Jones, P.D., Yang, J., Zhang, Y., Chiamvimonvat, N., Shyy, J.Y., Hammock, B.D. and Zhu, Y. (2009) Soluble epoxide hydrolase plays an essential role in angiotensin II-induced cardiac hypertrophy. Proc. Natl. Acad. Sci. USA. 106, 564-569. 
49 Gschwendtner, A., Ripke, S., Freilinger, T., Lichtner, P., Müller-Myhsok, B., Wichmann, H.E., Meitinger, T. and Dichgans, M. (2008) Genetic variation in soluble epoxide hydrolase (EPHX2) is associated with an increased risk of ischemic stroke in white Europeans. Stroke. 39, 1593-1596.

50 Ohtoshi, K., Kaneto, H., Node, K., Nakamura, Y., Shiraiwa, T., Matsuhisa, M. and Yamasaki, Y. (2005) Association of soluble epoxide hydrolase gene polymorphism with insulin resistance in type 2 diabetic patients. Biochem. Biophys. Res. Commun. 331, 347-350.

51 Imig, J.D. (2008) Eicosanoids and renal damage in cardiometabolic syndrome. Expert Opin. Drug Metab. Toxicol. 4, 165-74.

52 Zink, M.H., Oltman, C.L., Lu, T., Katakam, P.V., Kaduce, T.L., Lee, H., Dellsperger, K.C., Spector, A.A., Myers, P.R. and Weintraub, N.L. (2001) 12-lipoxygenase in porcine coronary circulation: implications for coronary vasoregulation. Am. J. Physiol. 280, H693-H704.

53 Tang, X., Holmes, B.B., Nithipatikom, K., Hillard, C.J., Kuhn, H. and Campbell, W.B. (2006) Reticulocyte 15-lipoxygenase-I is important in acetylcholine-induced endothelium-dependent vasorelaxation in rabbit aorta. Arterioscler. Thromb. Vasc. Biol. 26, 78-84.

54 Aggarwal, N.T., Gauthier, K.M. and Campbell, W.B. (2008) 15-Lipoxygenase metabolites contribute to age-related reduction in acetylcholine-induced hypotension in rabbits. Am. J. Physiol. Heart Circ. Physiol. 295, H89-H96

55 Tang, X., Aggarwal, N., Holmes, B.B., Kuhn, H. and Campbell, W.B. (2008) Agerelated decrease in 15-lipoxygenase contributes to reduced vasorelaxation in rabbit aorta. Am. J. Physiol. Heart Circ. Physiol. 294, H679-H687.

56 Aggarwal, N.T., Pfister, S.L. and Campbell, W.B. (2008) Hypercholesterolemia Enhances 15-Lipoxygenase-Mediated Vasorelaxation and Acetylcholine-Induced Hypotension. Arterioscler. Thromb. Vasc. Biol. 28, 2209-2215.

57 Aggarwal, N.T., Pfister, S.L., Gauthier, K.M., Chawengsub, Y., Baker, J.E. and Campbell W.B. (2009) Chronic hypoxia enhances 15-lipoxygenase mediated vasorelaxation in rabbit arteries. Am J Physiol Heart Circ Physiol. [Epub ahead of print

58 Quignard, J.F., Chataigneau, T., Corriu, C., Edwards, G., Weston, A.H., Félétou, M. and Vanhoutte, P.M. (2002) Endothelium-dependent hyperpolarization and lipoxygenase derived metabolites of arachidonic acid in the carotid artery of the guinea-pig. $\mathrm{J}$ Cardiovasc Pharmacol. 40, 467-477.

59 Randall, M.D., Kendall, D.A. and O'Sullivan, S. (2004) The complexities of the cardiovascular actions of cannbinoids. Br. J. Pharmacol. 142, 20-26.

60 Chataigneau, T., Félétou, M., Thollon, C., Villeneuve, N., Vilaine, J-P., Duhault, J. and Vanhoutte P.M. (1998) Cannabinoid $\mathrm{CB}_{1}$ receptor and endothelium-dependent hyperpolarisation in guinea-pig carotid, rat mesenteric and porcine coronary arteries. $\mathrm{Br}$. J. Pharmacol. 123, 968-974.

61 Vásquez-Vivar, J., Kalyanaraman, B. and Martásek, P. (2003) The role of tetrahydrobiopterin in superoxide generation from eNOS: enzymology and physiological implications. Free Radic. Res. 37, 121-127.

62 Capettini, L.S., Cortes, S.F., Gomes, M.A., Silva, G.A., Pesquero, J.L., Lopes, M.J., Teixeira, M.M. and Lemos, V.S. (2008) Neuronal nitric oxide synthase-derived hydrogen peroxide is a major endothelium-dependent relaxing factor. Am. J. Physiol. Heart Circ. Physiol. 295, H2503-H2511.

63 Drouin, A., Thorin-Trescases, N., Hamel, E., Falck, J.R. and Thorin, E. (2007) Endothelial nitric oxide synthase activation leads to dilatory $\mathrm{H} 2 \mathrm{O} 2$ production in mouse cerebral arteries. Cardiovasc. Res. 73: 73-81. 
64 Nardi, A. and Olesen, S.P. (2008) BK channel modulators: a comprehensive overview. Curr. Med. Chem. 15, 1126-1146.

65 Cohen, R.A., Plane, F., Najibi, S., Huk, I., Malinski, T. and Garland, C.J. (1997) Nitric oxide is the mediator of both endothelium-dependent relaxation and hyperpolarisation of the rabbit carotid artery. Proc. Natl. Acad. Sci. USA. 94:4193-4198.

66 Chauhan, S., Rahman, A., Nilsson, H., Clapp, L., MacAllister, R. and Ahluwalia, A. (2003) NO contributes to EDHF-like responses in rat small arteries: role of NO stores. Cardiovasc. Res. 57, 207-216.

67 Muller, B., Kleschyov, A.L., Alencar, J.L., Vanin, A. and Stoclet, J.C. (2002) Nitric oxide transport and storage in the cardiovascular system. Ann. N.Y. Acad. SCI. 962, 131-139.

68 Batenburg, W.W., De Vries, R., Saxena, P.R. and Danser, A.H. (2004) L-S nitrosothiols: endothelium-derived hyperpolarizing factors in porcine coronary arteries. J. Hypertens. 22, 1927-1936.

69 Félétou, M. and Vanhoutte, P.M. (2006) EDHF: where are we now? Arterioscler. Thromb. Vasc. Biol. 26, 1215-1225.

70 Brandes, R.P., Schmitz-Winnenthal, F-H., Félétou, M., Gödecke, A., Huang, P-L., Vanhoutte, P.M., Fleming, I. and Busse, R. (2000) An endothelium-derived hyperpolarizing factor distinct from NO and prostacyclin is a major endotheliumdependent vasodilator in resistancevessels of wild type and endothelial NO synthase knock-out mice. Proc. Natl. Acad. Sci. USA 97, 9747-9752.

71 Wu, Y., Huang, A., Sun, D., Falck, J.R., Koller, A. and Kaley, G. (2001) Genderspecific compensation for the lack of NO in the mediation of flow-induced arteriolar dilation. Am. J. Physiol. Heart Circ. Physiol. 280, H2456-H2461.

72 Scotland, R.S., Madhani, M., Chauhan, S., Moncada, S., Andresen, J., Nilsson, H., Hobbs, A.J. and Ahluwalia, A. (2005) Investigation of vascular responses in endothelial nitric oxide synthase/cyclooxygenase-1 double knock-out mice. Key role for endothelium-derived hyperpolarizing factor in the regulation of blood pressure in vivo. Circulation 111: 796-803.

73 Takaki, A., Morikawa, K., Tsutsui, M., Murayama, Y., Tekes, E., Yamagishi, H., Ohashi, J., Yada, T., Yanagihara, N. and Shimokawa, H. (2008) Crucial role of nitric oxide synthases system in endothelium-dependent hyperpolarization in mice. J. Exp. Med. 205, 2053-2063.

74 Ellis, A. and Triggle, C.R. (2003) Endothelium-derived reactive oxygen species: their relationship to endothelium-dependent hyperpolarization and vascular tone. Can. J. Physiol. Pharmacol. 81, 1013-1028.

75 Lucchesi, P.A., Belmadani, S. and Matrougui, K. (2005) Hydrogen peroxide acts as both vasodilator and vasoconstrictor in the control of perfused mesenteric resistance arteries. J. Hypertens. 23, 571-579.

76 Matoba, Y., Shimokawa, H., Nakashima, M., Hirakawa, Y., Mukai, Y., Hirano, K., Kanaide, H. and Takeshita, A. (2000) Hydrogen peroxide is an endothelium-derived hyperpolarizing factor in mice. J. Clin. Invest. 106, 1521-1530.

77 Morikawa, K., Shimokawa, H., Matoba, T., Kubota, H., Akaike, T., Talukder, M.A., Hatanaka, M., Fujiki, T., Maeda, H., Takahashi, S. and Takeshita, A. (2003) Pivotal role of $\mathrm{Cu}, \mathrm{Zn}$-superoxide dismutase in endothelium-dependent hyperpolarization. J. Clin. Invest. 112, 1871-1879.

78 Shimokawa, H. and Matoba, T. (2004) Hydrogen peroxide as an endothelium-derived hyperpolarizing factor. Pharmacol. Res. 49, 543-549.

79 Matoba, Y., Shimokawa, H., Kubota, H., Morikawa, K., Fujiki, T., Kunihiro, I., Mukai, Y., Hirakawa, Y. and Takeshita, A. (2002) Hydrogen peroxide is an endothelium- 
derived hyperpolarizing factor in human mesenteric artery. Biochem. Biophys. Res. Commun. 290, 909-913.

80 Miura, H., Bosnjak, J.J., Ning, G., Salto, T., Miura, M. and Gutterman, D.D. (2003) Role for hydrogen peroxide in flow-induced dilation of human coronary arterioles. Circ. Res. 92, e31-e40.

81 Edwards, D.H., Li, Y. and Griffith, T.M. (2008) Hydrogen peroxide potentiates the EDHF phenomenon by promoting endothelial Ca2+ mobilization. Arterioscler. Thromb. Vasc. Biol. 28, 1774-1781.

82 Cosentino, F. and Katusic, Z.S. (1995) Tetrahydrobiopterin and dysfunction of endothelial nitric oxide synthase in coronary arteries. Circulation 91, 139-144.

83 Cosentino, F., Barker, J.E., Brand, M.P., Heales, S.J., Werner, E.R., Tippins, J.R., West, N., Channon, K.M., Volpe, M. and Lüscher, T.F. (2001) Reactive oxygen species mediate endothelium-dependent relaxations in tetrahydrobiopterin-deficient mice. Arterioscler. Thromb. Vasc. Biol. 21, 496-502.

84 Phillips, S.A., Hatoum, O.A. and Gutterman, D.D. (2007) The mechanism of flowinduced dilation in human adipose arterioles involves hydrogen peroxide during CAD. Am. J. Physiol. Heart Circ. Physiol. 92, H93-H100.

85 Takaki, A., Morikawa, K., Murayama, Y., Yamagishi, H., Hosoya, M., Ohashi, J. and Shimokawa, H. (2008) Roles of Endothelial Oxidases in Endothelium-Derived Hyperpolarizing Factor Responses in Mice. J. Cardiovasc. Pharmacol. 52, 510-517.

86 Liu, Y., Zhao, H., Li, H., Kalyanaraman, B., Nicolosi, A.C. and Gutterman, D.D. (2003) Mitochondrial sources of $\mathrm{H} 2 \mathrm{O} 2$ generation play a key role in flow-mediated dilation in human coronary resistance arteries. Circ Res. 93, 573-580.

87 Larsen, B.T., Bubolz, A.H., Mendoza, S.A., Pritchard, K.A.Jr. and Gutterman, D.D. (2009) Bradykinin-Induced Dilation of Human Coronary Arterioles Requires NADPH Oxidase-Derived Reactive Oxygen Species. Arterioscler. Thromb. Vasc Biol. [Epub ahead of print].

88 Gluais, P., Edwards, G., Weston, A.H., Vanhoutte, P.M. and Félétou, M. (2005) Hydrogen peroxide and the endothelium-dependent hyperpolarization of the guinea-pig isolated carotid artery. Eur. J. Pharmacol. 513, 219-224

89 Wang R. (2002) Two's company, three's a crowd: can $\mathrm{H}_{2} \mathrm{~S}$ be the third endogenous gaseous transmitter? FASEB J. 16, 1792-1798.

90 Durante W. (2002) Carbon monoxide and bile pigments: surprising mediators of vascular function. Vasc. Med. 7,195-202.

$91 \mathrm{Wu}, \mathrm{L}$. and Wang R. (2005) Carbon monoxide: endogenous production, physiological functions, and pharmacological applications. Pharmacol. Rev. 57, 585-630.

92 Durante, W., Johnson, F.K. and Johnson, R.A. (2006) Role of carbon monoxide in cardiovascular function. J. Cell Mol. Med. 10, 672-686.

93 Chen, Y.H., Yet, S.F. and Perrella, M.A. (2003) Role of heme oxygenase-1 in the regulation of blood pressure and cardiac function. Exp. Biol. Med. (Maywood) 228, 447-453

94 Wang, R., Shamloul, R., Wang, X., Meng, Q. and Wu, L. (2006) Sustained normalization of high blood pressure in spontaneously hypertensive rats by implanted hemin pump. Hypertension. 48, 685-692.

95 Doré, S., Sampei, K., Goto, S., Alkayed, N.J., Guastella, D., Blackshaw, S., Gallagher, M., Traystman, R.J., Hurn, P.D., Koehler, R.C. and Snyder, S.H. (1999) Heme oxygenase-2 is neuroprotective in cerebral ischemia. Mol. Med. 5, 656-663.

96 Motterlini, R. (2007) Carbon monoxide-releasing molecules (CO-RMs): vasodilatory, anti-ischaemic and anti-inflammatory activities. Biochem. Soc. Trans. 35, 1142-1146. 
97 Zakhary, R., Gaine, S.P., Dinerman, J.L., Ruat, M., Flavahan, N.A. and Snyder, S.H. (1996) Heme oxygenase 2: endothelial and neuronal localization and role in endothelium-dependent relaxation. Proc. Natl. Acad. Sci. USA. 93, 795-798.

98 Baragatti, B., Brizzi, F., Barogi, S., Laubach, V.E., Sodini, D., Shesely, E.G., Regan, R.F. and Coceani, F. (2007) Interactions between NO, CO and an endothelium-derived hyperpolarizing factor (EDHF) in maintaining patency of the ductus arteriosus in the mouse. Br. J. Pharmacol. 151, 54-62.

99 Szabó C. (2007) Hydrogen sulphide and its therapeutic potential. Nat. Rev. Drug Discov. 6, 917-935.

100 Yang, G., Wu, L., Jiang, B., Yang, W., Qi, J., Cao, K., Meng, Q., Mustafa, A.K., Mu, W., Zhang, S., Snyder, S.H. and Wang, R. (2008) $\mathrm{H}_{2} \mathrm{~S}$ as a physiologic vasorelaxant: hypertension in mice with deletion of cystathionine gamma-lyase. Science. 322, 587590.

101 Zhao, W., Zhang, J., Lu, Y. and Wang, R. (2001) The vasorelaxant effect of $\mathrm{H}_{2} \mathrm{~S}$ as a novel endogenous gaseous $\mathrm{K}_{\mathrm{ATP}}$ channel opener. EMBO. J. 20, 6008-6016.

102 Powers, R.W., Gandley, R.E., Lykins, D.L. and Roberts, J.M. (2004) Moderate hyperhomocysteinemia decreases endothelial-dependent vasorelaxation in pregnant but not nonpregnant mice. Hypertension. 44, 327-333.

103 De Vriese, A.S., Blom, H.J., Heil, S.G., Mortier, S., Kluijtmans, L.A., Van de Voorde, J. and Lameire, N.H. (2004) Endothelium-derived hyperpolarizing factor-mediated renal vasodilatory response is impaired during acute and chronic hyperhomocysteinemia. Circulation. 109, 2331-2336.

104 Wang, Y., Zhao, X., Jin, H., Wei, H., Li, W., Bu, D., Tang, X., Ren, Y., Tang, C. and Du, J. (2009) Role of Hydrogen Sulfide in the Development of Atherosclerotic Lesions in Apolipoprotein E Knockout Mice. Arterioscler. Thromb. Vasc. Biol. [Epub ahead of print]

105 Brancaleone, V., Roviezzo, F., Vellecco, V., De Gruttola, L., Bucci, M. and Cirino, G. (2008) Biosynthesis of $\mathrm{H}(2) \mathrm{S}$ is impaired in non-obese diabetic (NOD) mice. Br. J. Pharmacol. 155, 673-680.

106 Suga, S., Itoh, H., Komatsu, Y., Ogawa, Y., Hama, N., Yoshimasa, T. and Nakao, K. (1993) Cytokine-induced c-type natriuretic peptide (CNP) secretion from vascular endothelial cells - evidence for CNP as a novel autocrine/paracrine regulator from endothelial cells. Endocrinology 133, 3038-3041.

107 Wei, C.M., Hu, S., Miller, V.M. and Burnett, J.C.Jr. (1994) Vascular actions of C-type natriuretic peptide in isolated porcine coronary arteries and coronary vascular smooth muscle cells. Biochem. Biophys. Res. Comm. 205, 765-771.

108 Honing, M.L., Smits, P., Morrison, P.J., Burnett, J.C.Jr. and Rabelink, T.J. (2001) Ctype natriuretic peptide-induced vasodilation is dependent on hyperpolarization in human forearm resistance vessels. Hypertension 37, 1179-1183.

109 Chauhan, S.D., Nilsson, H., Ahluwalia, A. and Hobbs, A.J. (2003) release of C-type natriuretic peptide accounts for the biological activity of endothelium-derived hyperpolarizing factor. Proc. Natl. Acad. Sci. USA 100, 1426-1431.

110 Villar, I.C., Panayiotou, C.M., Sheraz, A., Madhani, M., Scotland, R.S., Nobles, M., Kemp-Harper, B., Ahluwalia, A. and Hobbs, A.J. (2007) Definitive role for natriuretic peptide receptor-C in mediating the vasorelaxant activity of $\mathrm{C}$-type natriuretic peptide and endothelium-derived hyperpolarising factor. Cardiovasc. Res. 74, 515-525.

111 Barton, M., Beny, J.L., D'uscio, L.V., Wyss, T., Noll, G. and Luscher, T.F. (1998) Endothelium-independent relaxation and hyperpolarization to C-type natriuretic peptide in porcine coronary arteries. J. Cardiovasc. Pharmacol. 31, 377-383. 
112 Leuranguer, V., Vanhoutte, P.M., Verbeuren, T. and Félétou, M. (2008) C-type natriuretic peptide and endothelium-dependent hyperpolarization in the guinea-pig carotid artery. Br. J. Pharmacol. 153, 57-65.

113 Dora, K.A., Gallagher, N.T., McNeish, A. and Garland, C.J. (2008) Modulation of endothelial cell KCa3.1 channels during endothelium-derived hyperpolarizing factor signaling in mesenteric resistance arteries. Circ. Res. 102, 1247-1255.

114 McGuire, J.J., Hollenberg, M.D., Bennett, B.M. and Triggle, C.R. (2004) Hyperpolarization of murine small caliber mesenteric arteries by activation of endothelial proteinase-activated receptor 2. Can. J. Physiol. Pharmacol. 82, 1103-1112.

115 Ahluwalia, A. and Hobbs, A.J. (2005) Endothelium-derived C-type natriuretic peptide: more than just a hyperpolarizing factor. Trends Pharmacol. Sci. 26, 162-167.

116 Sandow, S.L. and Tare, M. (2007) C-type natriuretic peptide: a new endotheliumderived hyperpolarizing factor? Trends Pharmacol. Sci. 28, 61-67.

117 Marchenko, S.M. and Sage, S.O. (1996) Calcium-activated potassium channels in the endothelium of intact rat aorta. J. Physiol. 492, 53-60.

118 Bychkov, R., Burnham, M.P., Richards, G.R., Edwards, G., Weston, A.H., Félétou, M. and Vanhoutte, P.M. (2002) Characterization of a charybdotoxin-sensitive intermediate conductance $\mathrm{Ca} 2+$-activated $\mathrm{K}+$ channel in porcine coronary endothelium: relevance to EDHF. Br. J. Pharmacol. 137, 1346-1354.

119 Gauthier, K.M., Liu, C., Popovic, A., Albarwani, S. and Rusch, N.J. (2002) Freshly isolated bovine coronary endothelial cells do not express the BK Ca channel gene. J. Physiol. 545, 829-836.

120 Ledoux, J., Werner, M.E., Brayden, J.E. and Nelson, M.T. (2006) Calcium-activated potassium channels and the regulation of vascular tone. Physiology (Bethesda). 21, 6978.

121 Nelson, M.T., Cheng, H., Rubart, M., Santana, L.F., Bonev, A.D., Knot, H.J., Lederer, W.J. (1995) Relaxation of arterial smooth muscle by calcium sparks. Science 270, 633637.

122 Kwan, H.Y., Shen, B., Ma, X., Kwok, Y.C., Huang, Y., Man, Y.B., Yu, S., Yao, X. (2009).TRPC1 Associates With BKCa Channel to Form a Signal Complex in Vascular Smooth Muscle Cells. Circ Res. [Epub ahead of print].

123 Gauthier, K.M., Spitzbarth, N., Edwards, E.M. and Campbell, W.B. (2004) Apaminsensitive $\mathrm{K}+$ currents mediate arachidonic acid-induced relaxations of rabbit aorta. Hypertension. 43, 413-419.

124 Gebremedhin, D., Kaldunski, M., Jacobs, E.R., Harder, D.R. and Roman, R.J. (1996) Coexistence of two types of calcium activated potassium channels in rat renal arterioles. Am. J. Physiol. 270, F69-F81.

125 Quignard, J.F., Félétou, M., Edwards, G., Duhault, J., Weston, A.H. and Vanhoutte, P.M. (2000) Role of endothelial cell hyperpolarization in EDHF-mediated responses in the guinea-pig carotid artery. Br. J. Pharmacol. 129, 1103-1112.

126 Kohler, R., Wulff, H., Eichler, I., Kneifel, M., Neumann, D., Knorr, A., Grgic, I., Kampfe, D., Si, H., Wibawa, J., Real, R., Borner, K., Brakemeier, S., Orzechowski, H.D., Reusch, H.P., Paul, M., Chandy, K.G. and Hoyer, J. (2003) Blockade of the intermediate-conductance calcium-activated potassium channel as a new therapeutic strategy for restenosis. Circulation 108, 1119-1125.

127 Tharp, D.L., Wamhoff, B.R., Turk, J.R. and Bowles, D.K. (2006) Upregulation of intermediate-conductance $\mathrm{Ca} 2+$-activated $\mathrm{K}+$ channel (IKCa1) mediates phenotypic modulation of coronary smooth muscle. Am. J. Physiol Heart Circ. Physiol. 291, H2493-H2503. 
128 Burnham, M.P., Bychkov, R., Félétou, M., Richards, G.R., Vanhoutte, P.M., Weston, A.H. and Edwards, G. (2002) Characterization of an apamin-sensitive smallconductance $\mathrm{Ca}(2+)$-activated $\mathrm{K}(+)$ channel in porcine coronary artery endothelium: relevance to EDHF. Br. J. Pharmacol. 135, 1133-1143.

129 Kohler, R., Brakemeier, S., Kuhn, M., Behrens, C., Real, R., Degenhardt, C., Orzechowski, H.D., Pries, A.R., Paul, M. and Hoyer, J. (2001) Impaired hyperpolarization in regenerated endothelium after balloon catheter injury. Circ. Res. 89, 174-179.

130 Sandow, S.L., Neylon, C.B., Chen, M.X. and Garland, C.J. (2006) Spatial separation of endothelial small- and intermediate-conductance calcium-activated potassium channels $(\mathrm{K}(\mathrm{Ca}))$ and connexins: possible relationship to vasodilator function? J. Anat. 209, 689698.

131 Sandow, S.L., Haddock, R.E., Hill, C.E., Chadha, P.S., Kerr, P.M., Welsh, D.G. and Plane, F. (2008) What's where and why at a vascular myoendothelial microdomain signalling complex. Clin. Exp. Pharmacol. Physiol. [Epub ahead of print].

132 Absi, M., Burnham, M.P., Weston, A.H., Harno, E., Rogers, M. and Edwards, G. (2007) Effects of methyl beta-cyclodextrin on EDHF responses in pig and rat arteries; association between $\mathrm{SK}(\mathrm{Ca})$ channels and caveolin-rich domains. Br. J. Pharmacol. 151, 332-340.

133 Ledoux, J., Taylor, M.S., Bonev, A.D., Hannah, R.M., Solodushko, V., Shui, B., Tallini, Y., Kotlikoff, M.I. and Nelson, M.T. (2008) Functional architecture of inositol 1,4,5trisphosphate signaling in restricted spaces of myoendothelial projections. Proc. Natl. Acad. Sci. USA. 105, 9627-9632.

134 Syme, C.A., Gerlach, A.C., Singh, A.K. and Devor, D.C. (2000) Pharmacological activation of cloned intermediate and small conductance $\mathrm{Ca}(2+)$-activated $\mathrm{K}(+)$ channels. Am. J. Physiol. 278: C570-C581.

135 Edwards, G., Gardener, M.J., Félétou, M., Brady G., Vanhoutte, P.M. and Weston, A.H. (1999) Further investigation of endothelium-derived hyperpolarizing factor (EDHF) in rat hepatic artery: studies using 1-EBIO and ouabain. Br. J. Pharmacol. 128: 1064-1070.

136 Coleman, H.A., Tare, M. and Parkington H.C. (2001) EDHF is not $\mathrm{K}^{+}$but may be due to spread of current from the endothelium in guinea-pig arterioles. Am. J. Physiol. 280, H2478-H2483.

137 Sokoya, E.M., You, J. and Chen J. (2007) DCEBIO-mediated dilations are attenuated in the female rat middle cerebral artery. J. Vasc. Res. 44, 169-174.

138 Leuranguer, V., Gluais, P., Vanhoutte, P.M., Verbeuren, T.J. and Félétou, M. (2008) Openers of calcium-activated potassium channels and endothelium-dependent hyperpolarizations in the guinea pig carotid artery. Naunyn Schmiedebergs Arch. Pharmacol. 377, 101-109.

139 Sankaranarayanan, A., Raman, G., Busch, C., Schultz, T., Zimin, P.I., Hoyer, J., Kohler, R., Wulff, H. (2009) SKA-31, a New Activator of KCa2 and KCa3.1 Potassium Channels, Potentiates the EDHF Response and Lowers Blood Pressure. Mol. Pharmacol. 75, 281-295.

140 Busse, R., Fichtner, H., Luckhoff, A. \& Kohlhardt, M. (1988) Hyperpolarization and increased free calcium in acetylcholine-stimulated endothelial cells. Am. J. Physiol. 255, H965-H969.

141 Luckhoff, A. and Busse, R. (1990) Activators of potassium channels enhance calcium influx into endothelial cells as a consequence of potassium currents. Naunyn Schmiedebergs Arch. Pharmacol. 342, 94-99.

142 Stankevicius, E., Lopez-Valverde, V., Rivera, L., Hughes, A.D., Mulvany, M.J. and Simonsen, U. (2006) Combination of $\mathrm{Ca} 2+$-activated $\mathrm{K}+$ channel blockers inhibits 
acetylcholine-evoked nitric oxide release in rat superior mesenteric artery. Br. J. Pharmacol. 149, 560-572.

143 Sheng, J.Z. and Braun, A.P. (2007) Small- and intermediate-conductance Ca2+activated $\mathrm{K}+$ channels directly control agonist-evoked nitric oxide synthesis in human vascular endothelial cells. Am. J. Physiol. Cell Physiol. 293, C458-C467.

144 Griffith, T.M. (2004) Endothelium-dependent smooth muscle hyperpolarization: do gap junctions provide a unifying hypothesis? Br. J. Pharmacol. 141, 881-903.

145 Lang, N.N., Luksha, L., Newby, D. and Kublickiene, K. (2006) Connexin 43 Mediates Endothelium-Derived Hyperpolarising Factor Induced Vasodilatation in Subcutaneous Resistance Arteries from Healthy Pregnant Women. Am. J. Physiol. Heart. Circ. Physiol. 292, H1026-H1032.

146 Isakson, B.E., Best, A.K. and Duling, B.R. (2008) Incidence of protein on actin bridges between endothelium and smooth muscle in arterioles demonstrates heterogeneous connexin expression and phosphorylation. Am J Physiol Heart Circ Physiol. 294: H2898-H2904.

147 Sandow, S.L. and Hill, C.E. (2000) Incidence of myo-endothelial gap junctions in the proximal and distal mesenteric arteries of the rat is suggestive of a role in endotheliumderived hyperpolarizing factor-mediated responses. Cir. Res. 86, 341-346.

148 Hwa, J.J., Ghibaudi, L., Williams, P. and Chaterjee, M. (1994) Comparison of acetylcholine-dependent relaxation in large and small arteries of rat mesenteric vascular bed. Am. J. Physiol. 266, H952-H958.

149 Shimokawa, H., Yasutake, H., Fujii, K., Owada, M.K., Nakaike, R., Fukumoto, Y., Takayanagani, T., Nagao, T., Egashira, K., Fujishima, M. and Takeshita, A. (1996) The importance of the hyperpolarizing mechanism increases as the vessel size decrease in endothelium-dependent relaxations in rat mesenteric circulation. J. Cardiovasc. Pharmacol. 28, 703-711.

150 Dora, K.A., Doyle, M.P. and Duling, B.R. (1997) Elevation of intracellular calcium in smooth muscle causes endothelial cell generation of NO in arterioles. Proc. Natl. Acad. Sci. USA 94, 6529-6534.

151 Yashiro, Y. and Duling, B.R. (2000) Integrated $\mathrm{Ca}(2+)$ signaling between smooth muscle and endothelium of resistance vesels. Cir. Res. 87, 1048-1054.

152 Dora KA. (2001) Intercellular Ca2+ signalling: the artery wall. Semin. Cell. Dev. Biol. 12, 27-35.

153 Beny, J-L. and Pacicca, C. (1994) Bidirectional electrical communication between smooth muscle and endothelial cells in the pig coronary artery. Am. J. Physiol. 266, H1465-H1472.

154 Marchenko, S.M. and Sage, S.O. (1994) Smooth muscle cells affect endothelial membrane potential in rat aorta. Am. J. Physiol. 267, H804-H811.

155 Emerson, G.G. and Segal, S.S. (2000) Electrical coupling between endothelial cells and smooth muscle cells in hamster feed arteries: role in vasomotor control. Circ. Res. 87, 474-479.

156 Emerson, G.G. and Segal, S.S. (2000) Endothelial cell pathway for conduction of hyperpolarization and vasodilation aong hamster feed artery. Circ. Res. 86, 94-100.

157 De Wit, C., Roos, F., Bolz, S.S., Kirchhoff, S., Kruge, O., Willecke, K. and Pohl, U. (2000) Impaired conduction of vasodilatation along arterioles in connexin 40-deficient mice. Circ. Res. 86, 649-655.

158 Chaytor, A.Y., Evans, W.H. and Griffith T.M. (1998) Central role of heterocellular gap junction communication in endothelium-dependent relaxations of rabbit arteries. J. Physiol. 508, 561-73. 
159 Edwards, G., Félétou, M., Gardener, M.J., Thollon, C., Vanhoutte, P.M. and Weston, A.H. (1999) Role of gap junctions in the responses to EDHF in rat and guinea-pig small arteries. Br. J. Pharmacol. 128, 1788-1794.

160 Edwards G., Thollon C., Gardener M.J., Félétou M., Vilaine J-P., Vanhoutte P.M. and Weston A.H. (2000) Role of gap junctions and EETs in endothelium-dependent hyperpolarization of porcine coronary artery. Br. J. Pharmacol. 129, 1145-1162.

161 Mather, S., Dora, K.A., Sandow, S.L., Winter, P. and Garland, C.J. (2005) Rapid endothelial cell-selective loading of connexin 40 antibody blocks endothelium-derived hyperpolarizing factor dilation in rat small mesenteric arteries. Circ. Res. 97, 399-407.

162 Figueroa, X.F. and Duling BR. (2008) Dissection of two Cx37-independent conducted vasodilator mechanisms by deletion of $\mathrm{Cx} 40$ : electrotonic versus regenerative conduction. Am J Physiol Heart Circ Physiol. 295, H2001-2007.

163 Gluais, P., Edwards, G., Weston, A.H., Falck, J.R., Vanhoutte, P.M. and Félétou, M. (2005) $\mathrm{SK}_{\mathrm{Ca}}$ and $\mathrm{IK}_{\mathrm{Ca}}$ in the endothelium-dependent hyperpolarization of the guinea-pig isolated carotid artery. Br. J. Pharmacol. 144, 477-485.

164 De Wit, C., Boettcher, M. and Schmidt, V.J. (2008) Signaling across myoendothelial gap junctions--fact or fiction? Cell. Commun. Adhes. 15: 231-245.

165 De Vriese, A.S., Van de Voorde and J. Lameire, N.H. (2002) Effects of connexinmimetic peptides on nitric oxide synthase- and cyclooxygenase-independent renal vasodilatation. Kidney Int. 61, 177-185.

166 Edwards, G., Dora, K.A., Gardener, M.J., Garland, C.J. and Weston A.H. (1998) K ${ }^{+}$is an endothelium-derived hyperpolarizing factor in rat arteries. Nature 396, 269-272.

167 Hendrickx, H. and Casteels, R. (1974) Electrogenic sodium pump in arterial smooth muscle cells. Pflugers Arch. 346, 299-306.

168 Nelson, M.T. and Quayle J.M. (1995) Physiological roles and properties of potassium channels in arterial smooth muscle. Am J Physiol. 268, C799-C822.

169 Prior, H.M., Webster, N., Quinn, K., Beech, D.J. and Yates, M.S. (1998) K(+)-induced dilation of a small renal artery: no role for inward rectifier $\mathrm{K}^{+}$channels. Cardiovasc. Res. 37, 780-790.

170 Edwards, G., Gardener, M.J., Félétou, M., Brady, G., Vanhoutte, P.M. and Weston, A.H. (1999) Further investigation of endothelium-derived hyperpolarizing factor (EDHF) in rat hepatic artery: studies using 1-EBIO and ouabain. Br. J. Pharmacol. 128, 1064-1070.

171 Dora, K.A. and Garland, C.J. (2001) Properties of smooth muscle hyperpolarization and relaxation to $\mathrm{K}^{+}$in the rat isolated mesenteric artery. Am. J. Physiol. 280, H2424H2429.

172 McGuire, J.J., Hollenberg, M.D., Andrade-Gordon, P. and Triggle, C.R. (2002) Multiple mechanisms of vascular smooth muscle relaxation by the activation of proteinase-activated receptor 2 in mouse mesenteric arterioles. Br. J. Pharmacol. 135, 155-169.

173 Beny, J-L. and Schaad, O. (2000) An evaluation of potassium ions as endotheliumderived hyperpolarizing factor in porcine coronary arteries. Br. J. Pharmacol. 131, 965973.

174 Nelli, S., Wilson, W.S., Laidlaw, H., Llano, A., Middleton, S., Price, A.G. and Martin, W. (2003) Evalauation of potassium ions as the endothelium-derived hyperpolarizing factor (EDHF) in the bovine coronary artery. Br. J. Pharmacol. 139, 982-988.

175 Randriamboavonjy, V., Busse, R. and Fleming, I. (2003) 20-HETE-induced contraction of small coronary arteries depends on the activation of Rho-kinase. Hypertension. 41, 801-806. 
176 Büssemaker, E., Popp, R., Binder, J., Busse, R. and Fleming, I. (2003) Characterization of the endothelium-derived hyperpolarizing factor (EDHF) response in the human interlobar artery. Kidney Int. 63, 1749-1755.

177 Torondel, B., Vila, J.M., Segarra, G., Lluch, P., Medina, P., Martinez-Leon, J, Ortega, J. and Lluch, S. (2004) Endothelium-dependent responses in human isolated thyroid arteries from donors. J. Endocrinol. 181, 379-384.

178 Weston, A.H., Absi, M., Ward, D.T., Ohanian, J., Dodd, R.H., Dauban, P., Petrel, C., Ruat, M. and Edwards, G. (2005) Evidence in favor of a calcium-sensing receptor in arterial endothelial cells: studies with calindol and Calhex 231. Circ Res. 97: 391-398.

179 Kansui, Y., Garland, C.J. and Dora, K.A. (2008) Enhanced spontaneous Ca2+ events in endothelial cells reflect signalling through myoendothelial gap junctions in pressurized mesenteric arteries. Cell Calcium. 44: 135-146.

180 Isakson, B.E., Ramos, S.I. and Duling, B.R. (2007) Ca2+ and inositol 1,4,5trisphosphate-mediated signaling across the myoendothelial junction. Circ Res. 100: 246-254.

181 Richards, G.R., Weston, A.H., Burnham, M.P., Félétou, M., Vanhoutte, P.M. and Edwards, G. (2001) Suppression of $\mathrm{K}(+)$-induced hyperpolarization by phenylephrine in rat mesenteric artery: relevance to studies of endothelium-derived hyperpolarizing factor. Br. J. Pharmacol. 134, 1-5.

182 Weston, A.H., Absi, M., Harno, E., Geraghty, A.R., Ward, D.T., Ruat, M., Dodd, R.H., Dauban, P. and Edwards, G. (2008) The expression and function of $\mathrm{Ca}(2+)$-sensing receptors in rat mesenteric artery; comparative studies using a model of type II diabetes. Br. J. Pharmacol. 154: 652-662.

183 Smajilovic, S., and Tfelt-Hansen, J. (2008) Novel role of the calcium-sensing receptor in blood pressure modulation. Hypertension. 52: 994-1000.

184 Quignard, J-F, Félétou, M., Duhault, J. and Vanhoutte, P.M. (1999) Potassium ions as endothelium-derived hyperpolarizing factors in the isolated carotid artery of the guineapig. Br. J. Pharmacol. 127, 27-34.

185 Dong, H., Jiang, Y., Cole, W.C. and Triggle, C.R. (2000) Comparison of the pharmacological properties of EDHF-mediated vasorelaxation in the guinea-pig cerebral and mesenteric resistance vessels. Br. J. Pharmacol. 130, 1983-1991.

186 Taylor, M.S., Bonev, A.D., Gross, T.P., Eckman, D.M., Brayden, J.E., Bond, C.T, Adelman J.P. and Nelson, M.T. (2003) Altered expression of small-conductance $\mathrm{Ca}^{2+}$ activated $\mathrm{K}^{+}$(SK3) channels modulate arterial tone and blood pressure. Circ. Res. 93, 124-131.

187 Si, H., Heyken, W.T., Wolfle, S.E., Tysiac, M., Schubert, R., Grgic, I., Vilianovich, L., Giebing, G., Maier, T., Gross, V., Bader, M., de Wit, C., Hoyer, J. and Köhler, R. (2006) Impaired Endothelium-Derived Hyperpolarizing Factor-Mediated Dilations and Increased Blood Pressure in Mice Deficient of the Intermediate-Conductance $\mathrm{Ca}^{2+}$ Activated K ${ }^{+}$Channel. Circ. Res. 99, 537-544.

188 De Wit, C. (2008) Calcium-activated potassium channels and EDHF-mediated responses. Basic Clin. Pharmacol. Toxicol. 102: 8.

189 Brähler, S., Grgic, I., Busch, C., Kacik, M., Hoyer, J. and Köhler, R. (2008) EDHFsignalling and arterial blood pressure in mice deficient of endothelial $\mathrm{KCa}$-channels. Basic Clin. Pharmacol. Toxicol. 102, 9.

190 Simon, A.M. and McWhorter, A.R. (2003) Decreased intercellular dye-transfer and downregulation of non-ablated connexins in aortic endothelium deficient in connexin 37 or connexin40. J. Cell Sci. 116, 2223-2236. 
191 Wagner, C., de Wit, C., Kurtz, L., Grunberger, C., Kurtz, A. and Schweda, F. (2007) Connexin40 is essential for the pressure control of renin synthesis and secretion. Circ. Res. 100, 556-563.

192 Simon, A.M. and McWhorter, A.R. (2002) Vascular abnormalities in mice lacking the endothelial gap junction protein connexin 37 and connexin40. Dev. Biol. 251, 206-220.

193 De Wit, C., Roos, F., Bolz, S.S. and Pohl, U. (2003) Lack of vascular connexin 40 is associated with hypertension and irregular arteriolar vasomotion. Physiol. Genomics. 13, 169-177.

194 Figueroa, X.F., Paul, D.L., Simon, A.M., Goodenough, D.A., Day, K.H., Damon, D.N. and Duling, B.R. (2003) Central role of connexin 40 in the propagation of electrically activated vasodilation in mouse cremasteric arterioles in vivo. Circ. Res. 92, 793-800.

195 Félétou, M. and Vanhoutte, PM. (2004) EDHF: new therapeutic targets? Pharmacological Res. 49, 565-580.

196 Matsumoto, T., Kobayashi, T., Wakabayashi, K. and Kamata, K. (2005) Cilostazol improves endothelium-derived hyperpolarizing factor-type relaxation in mesenteric arteries from diabetic rats. Am. J. Physiol. Heart Circ. Physiol. 289, H1933-H18940.

197 Neylon, C.B., Lang, R.J., Fu, Y., Bobik, A. and Reinhart, P.H. (1999) Molecular cloning and characterization of the intermediate-conductance $\mathrm{Ca}(2+)$-activated $\mathrm{K}(+)$ channel in vascular smooth muscle: relationship between $\mathrm{K}(\mathrm{Ca})$ channel diversity and smooth muscle function. Circ. Res. 85, 33-43.

198 Tharp, D.L,. Wamhoff, B.R.,Wulff, H., Raman, G., Cheong, A. and Bowles, D.K. (2008) Local delivery of the KCa3.1 blocker, TRAM-34, prevents acute angioplastyinduced coronary smooth muscle phenotypic modulation and limits stenosis. Arterioscler Thromb Vasc Biol. 28, 1084-1089.

199 Wulff, H., Miller, M.J., Haensel, W., Grissner, S., Cahalan, M.D. and Chandy, K.G. (2000) Design of potent and selective inhibitor of the intermediate-conductance $\mathrm{Ca}^{2+}$ activated $\mathrm{K}^{+}$channel, IKCa1: a potential immunosuppressant. Proc. Natl. Acad, Sci. USA. 97, 8151-8156.

200 Toyama, K., Wulff, H., Chandy, K.G., Azam, P., Raman, G., Saito, T., Fujiwara, Y., Mattson, D.L., Das, S., Melvin, J.E., Pratt, P.F., Hatoum, O.A., Gutterman, D.D., Harder, D.R. and Miura H. (2008) The intermediate-conductance calcium-activated potassium channel $\mathrm{KCa} 3.1$ contributes to atherogenesis in mice and humans. J. Clin. Invest. 118, 3025-3037.

201 Grgic, I., Eichler, I., Heinau, P., Si, H., Brakemeier, S., Hoyer, J. \& Kohler, R. (2005) Selective blockade of the intermediate-conductance $\mathrm{Ca} 2+$-activated $\mathrm{K}+$ channel suppresses proliferation of microvascular and macrovascular endothelial cells and angiogenesis in vivo. Arterioscler. Thromb. Vasc. Biol. 25, 704-709.

202 Jäger, H., Dreker, T., Buck, A., Giehl, K., Gress, T. and Grissmer, S. (2004) Blockage of intermediate-conductance $\mathrm{Ca} 2+$-activated $\mathrm{K}+$ channels inhibit human pancreatic cancer cell growth in vitro. Mol. Pharmacol. 65, 630-638.

203 Wang, Z.H., Shen, B., Yao, H.L., Jia, Y.C., Ren, J., Feng, Y.J. and Wang, Y.Z. (2007) Blockage of intermediate-conductance- $\mathrm{Ca}(2+)$-activated $\mathrm{K}(+)$ channels inhibits progression of human endometrial cancer. Oncogene. 26, 5107-5114.

204 Nilius, B. and Voets, T. (2004) Diversity of TRP channel activation. Novartis Found Symp. 258, 140-149.

205 Hartmannsgruber, V., Heyken, W.T., Kacik, M., Kaistha, A., Grgic, I., Harteneck, C., Liedtke, W., Hoyer, J. and Köhler, R. (2007) Arterial response to shear stress critically depends on endothelial TRPV4 expression. PLoS ONE. 2, e827.

206 Zhang, D.X., Mendoza, S.A., Bubolz, A.H., Mizuno, A., Ge, Z.D., Li, R., Warltier, D.C., Suzuki, M. and Gutterman, D.D. (2009) Transient Receptor Potential Vanilloid 
Type 4-Deficient Mice Exhibit Impaired Endothelium-Dependent Relaxation Induced by Acetylcholine In Vitro and In Vivo. Hypertension. [Epub ahead of print].

207 Willette, R.N., Bao, W., Nerurkar, S., Yue, T.L., Doe, C.P., Stankus, G., Turner, G.H., Ju, H., Thomas, H., Fishman, C.E., Sulpizio, A., Behm, D.J., Hoffman, S., Lin, Z., Lozinskaya, I., Casillas, L.N., Lin, M., Trout, R.E., Votta, B.J., Thorneloe, K., Lashinger, E.S., Figueroa, D.J., Marquis, R. and Xu, X. (2008) Systemic activation of the transient receptor potential vanilloid subtype 4 channel causes endothelial failure and circulatory collapse: Part 2. J. Pharmacol. Exp. Ther. 326, 443-452.

208 Kjølbye, A.L., Knudsen, C.B., Jepsen, T., Larsen, B.D. and Petersen, J.S. (2003) Pharmacological characterization of the new stable antiarrhythmic peptide analog AcD-Tyr-D-Pro-D-Hyp-Gly-D-Ala-Gly-NH2 (ZP123): in vivo and in vitro studies. J. Pharmacol. Exp. Ther. 306, 1191-1199.

209 Lang, N.N., Myles, R.C., Burton, F.L., Hall, D.P., Chin, Y.Z., Boon, N.A. and Newby, D.E. (2008) The vascular effects of rotigaptide in vivo in man. Biochem. Pharmacol. 76, 1194-1200. 


\section{Figure legends}

Figure 1: Endothelium-dependent relaxations and contractions

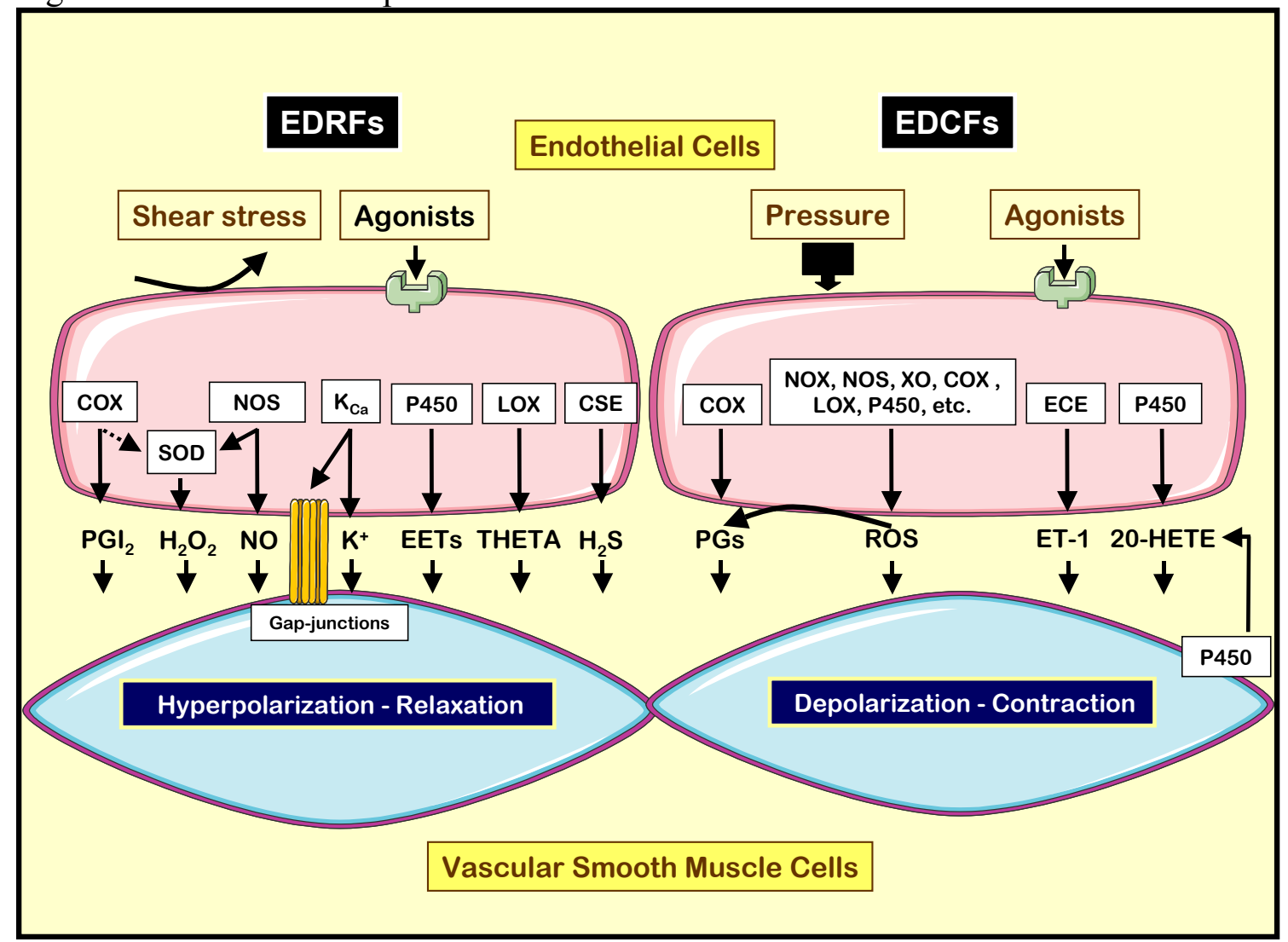

Endothelial cells synthesize and release various vasoactive factors and therefore maintain the balance between vasodilatation and vasoconstriction. Upsetting this tightly regulated balance contributes to endothelial dysfunction [2].

EDRFs: endothelium-derived relaxing factors; EDCFs: endothelum-derived contracting factors; COX: cyclooxygenases; SOD: superoxide dismutases; NOS: nitric oxie synthases; $\mathrm{K}_{\mathrm{Ca}}$ : calcium-activated potassium channels; P450: cytochrome P450; LOX: lipoxygenases; CSE: cystathionine $\gamma$-lyase; XO: xanthine oxidase; ECE: endothelin converting enzyme; $\mathrm{PGI}_{2}$ : prostacyclin; $\mathrm{H}_{2} \mathrm{O}_{2}$ : hydrogen peroxide; $\mathrm{K}^{+}$: potassium ions; EETs: epoxyeicosatrienoic acids; THETA: trihydroxyeicosatrienoic acid; $\mathrm{H}_{2} \mathrm{~S}$ : hydrogen sulfide; PGs: prostaglandins; ROS: reactive oxygen species; ET-1: endothelin-1; 20-HETE: 20-hydroxyeicosatetraenoic acid. 
Figure 2: Calcium-activated potassium channels in the vascular wall and EDHF-mediated responses

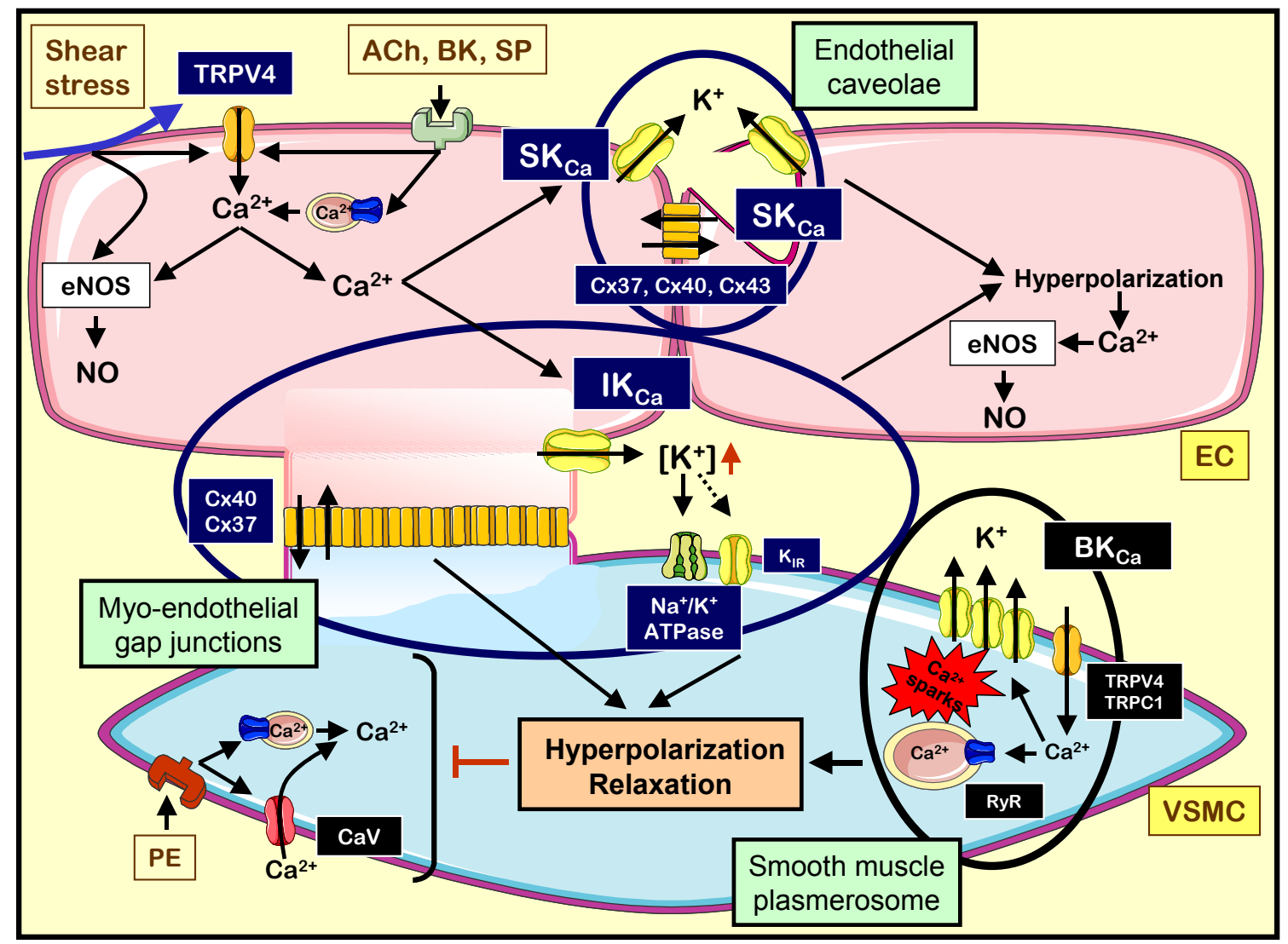

The three subtypes of calcium-activated potassium channels of large $\left(\mathrm{BK}_{\mathrm{Ca}}\right)$, intermediate $\left(\mathrm{IK}_{\mathrm{Ca}}\right)$ and small conductance $\left(\mathrm{SK}_{\mathrm{Ca}}\right)$ are present in the vascular wall but with very specific cellular and subcellular localization. $\mathrm{BK}_{\mathrm{Ca}}$ channels are expressed preferentially in discrete vascular smooth muscle area, smooth muscle plasmerosome, associated with endoplasmic reticulum. They form signal complexes with canonical or vanilloid transient receptor potential channels 1 (TRPC1 orTRPV4). The $\mathrm{IK}_{\mathrm{Ca}}$ and $\mathrm{SK}_{\mathrm{Ca}}$ channels (especially the SK3 $\alpha$ subunit) are constitutively expressed in endothelial cells. $\mathrm{SK}_{\mathrm{Ca}}$ are diffusely distributed over the plasma membrane with preferential locations at sites of homocellular endothelial gap junctions and caveolin-rich domains and are associated with various connexins ( $\mathrm{Cx}$ ) (Endothelial caveolae). $\mathrm{IK}_{\mathrm{Ca}}$ are preferentially localized within the endothelial projections through the internal elastic lamina (myo-endothelial gap junctions).

The activation of endothelial receptors and the shear stress exerted by the flowing blood increase endothelial $\left[\mathrm{Ca}^{2+}\right]_{\mathrm{i}}$. and activates endothelial NO-synthase (eNOS) as well as $\mathrm{SK}_{\mathrm{Ca}}$ and $\mathrm{IK}_{\mathrm{Ca}}$ channels. The subsequent endothelial hyperpolarization favors the entry of calcium as a positive feedback loop. The hyperpolarization can be conducted through myoendothelial gap junctions composed of $\mathrm{Cx} 40$ and possibly $\mathrm{Cx} 37$ to the underlying vascular smooth muscle. Additionally, accumulation of potassium ions in the intercellular space can hyperpolarize the smooth muscle cells by activating $\mathrm{Na}^{+} / \mathrm{K}^{+}$-ATPase and inwardly rectifying potassium channels $\left(\mathrm{K}_{\mathrm{IR}}\right)$.

EC: endothelial cells; VSMC: vascular smooth muscle cells; ACh: acetylcholine, BK: bradykinin; SP: substance P; PE: phenylephrine; RyR: ryanodine receptor; $\mathrm{CaV}$ : voltageactivated calcium channels. 
Figure 3: Myoendothelial projections

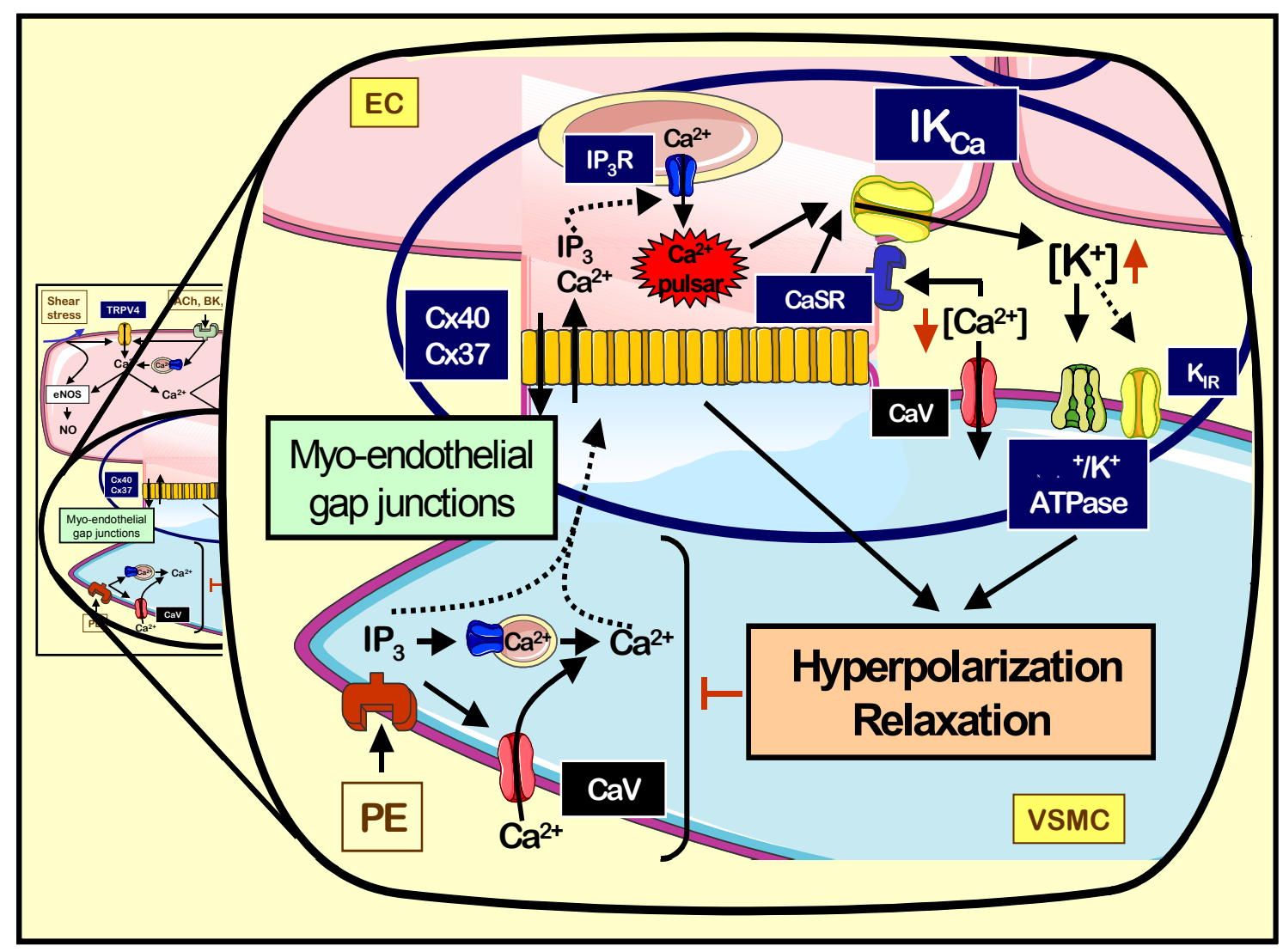

Stimulation of vascular smooth muscle cells by contractile agonists, for instance phenylephrine (PE) increases the intracellular $\mathrm{Ca}^{2+}$ concentration via the release of calcium from internal stores, through the production of inositol trisphosphate $\left(\mathrm{IP}_{3}\right)$, and via the entry of calcium, through voltage-activated calcium channels $(\mathrm{CaV})$. In order to prevent excessive contractions, various negative feedback mechanisms leading to smooth muscle hyperpolarization can operate, i.e. the increase in $\mathrm{Ca}^{2+}$ can activate smooth muscle cells $\mathrm{BK}_{\mathrm{Ca}}$, $\mathrm{Ca}^{2+}$ and $\mathrm{IP}_{3}$ can diffuse to the endothelial cells through myo-endothelial gap-junctions and activate $\mathrm{IK}_{\mathrm{Ca}}$ (and possibly $\mathrm{SK}_{\mathrm{Ca}}$ ) either directly or via the generation of calcium pulsars, depletion of $\mathrm{Ca}^{2+}$ in the intercellular space at sites of myo-endothelial projections, via the activation of local $\mathrm{CaV}$, can be sensed by the calcium sensing receptor (CaSR) and thus unable the activation of IK1. Therefore, intracellular $\mathrm{Ca}^{2+}$ concentrations (and $\mathrm{IP}_{3}$ ) as well as intercellular concentrations of $\mathrm{Ca}^{2+}$ and $\mathrm{K}^{+}$, as surrogates of cellular activation, could finely regulate the membrane potential of endothelial and vascular smooth muscle cells and therefore vascular tone (schematic based on references 113 and 133).

EC: endothelial cells; VSMC: vascular smooth muscle cells; $\mathrm{CX}$ : connexins; $\mathrm{IK}_{\mathrm{Ca}}$ : calciumactivated potassium channels of intermediate conductance; $\mathrm{K}_{\mathrm{IR}}$ : inwardly rectifying potassium channels; $\mathrm{IP}_{3} \mathrm{R}$ : $\mathrm{IP}_{3}$ receptor; 


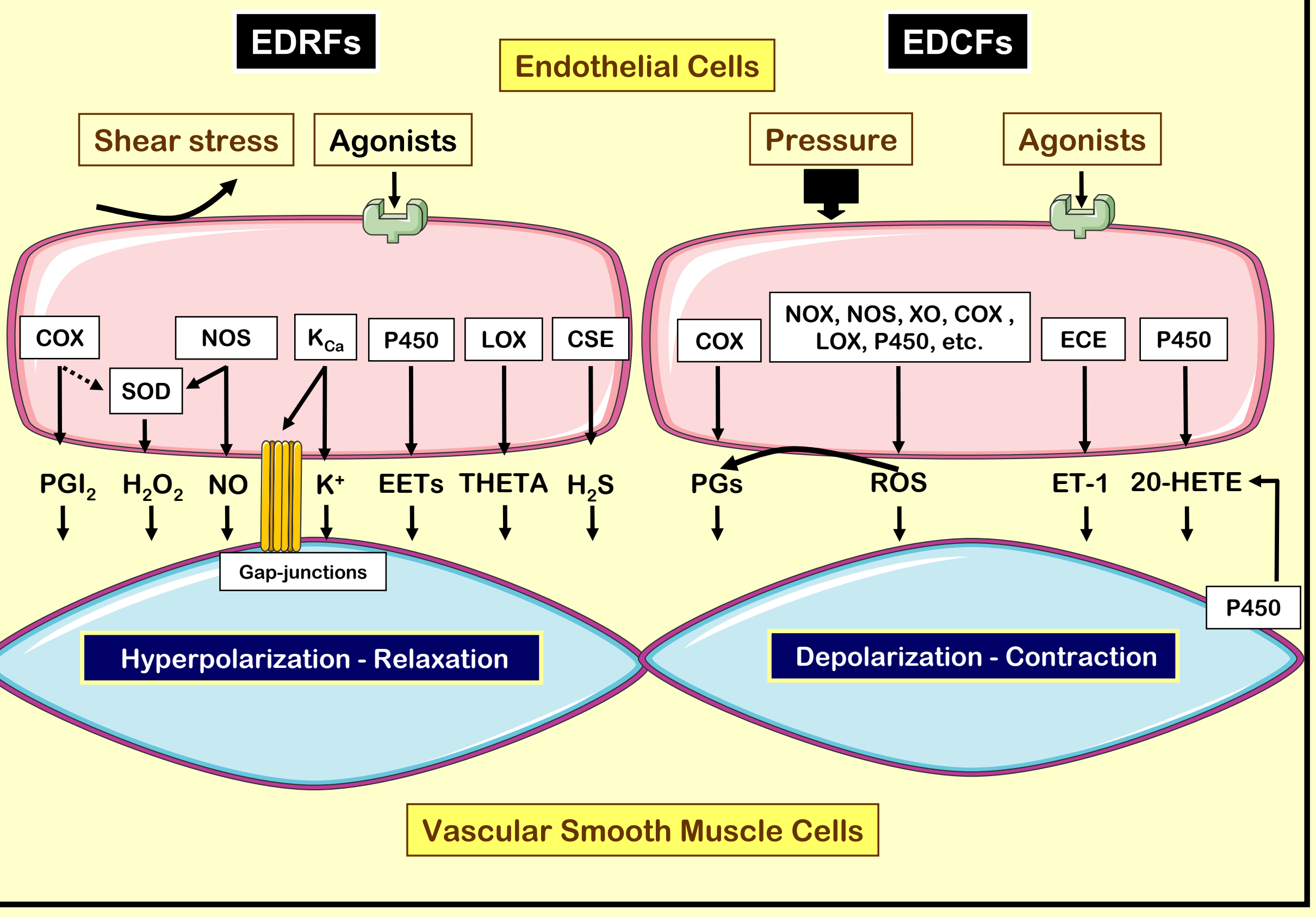




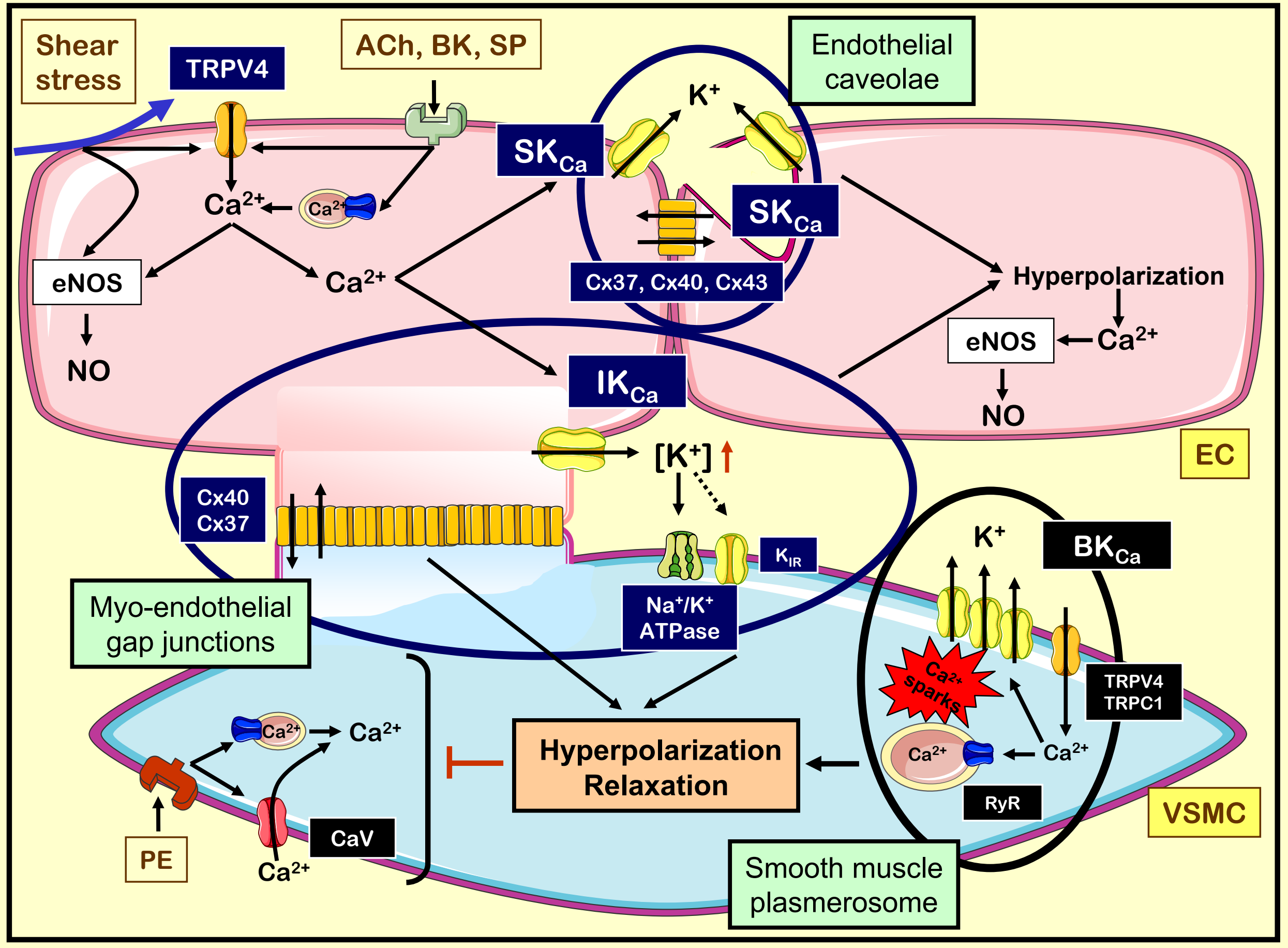




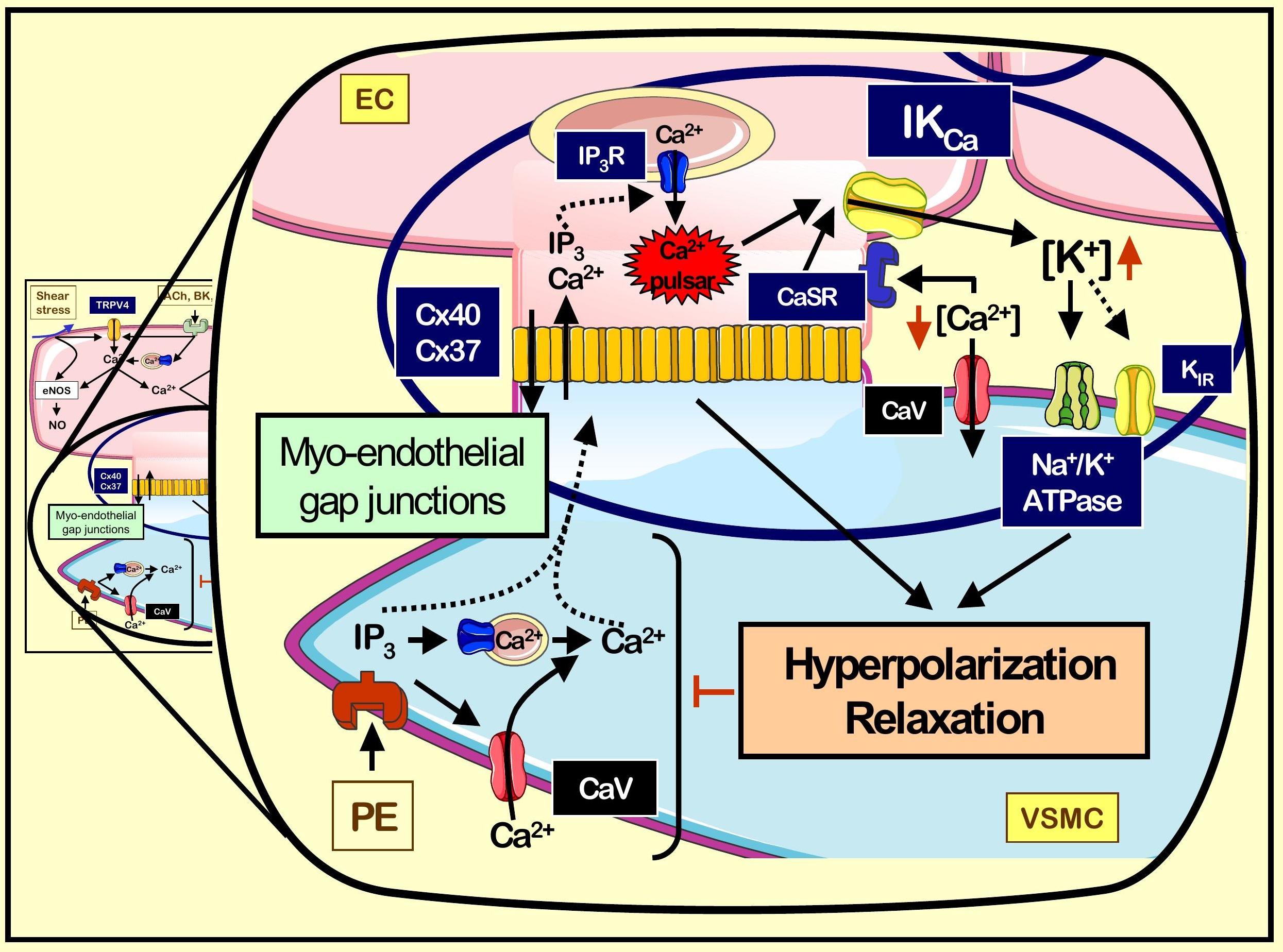

